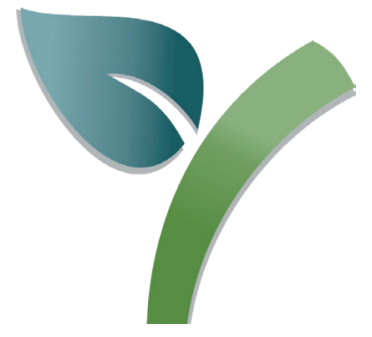

\title{
CRISPR/CAS: DO SISTEMA IMUNE DE PROCARIOTOS AO CONTROLE DE DOENÇAS DE PLANTAS
}

\author{
Leila Lourenço Furtado ${ }^{1}$, Camila de Moraes Rego-Machado ${ }^{1,2}$, \\ Gustavo Marin-Ramirez ${ }^{3}$, Natália Chagas Freitas², \\ Hugo Bruno Correa Molinari², Thaís Ribeiro Santiago ${ }^{1, *}$
}

\section{RESUMO}

A tecnologia de edição genômica CRISPR/Cas, desenvolvida a partir do sistema imune bacteriano, vem revolucionando diversas áreas, incluindo o controle de doenças de plantas. Considerado uma técnica simples, com alta especificidade e fácil uso, o sistema CRISPR/Cas permite a manipulação genética até mesmo de culturas com genoma com alta poliploidia, longo ciclo de vida e moroso processo de regeneração. Com isso, a técnica fornece uma oportunidade de criar novas cultivares com características benéficas de forma rápida, eficiente e sustentável para o controle de fitopatógenos. Nesta revisão, foram descritos o histórico da descoberta, funcionamento, adaptação e mecanismos de reparo do sistema CRISPR/Cas com foco na edição genômica de plantas. Além disso, abordou-se os avanços recentes relacionados à descoberta de variantes e engenharia das enzimas Cas, estratégias para o aumento da especificidade e efetividade da tecnologia, formas de entrega das biomoléculas em plantas e outras aplicações do sistema CRISPR/Cas, tais como a regulação de genes e detecção dos sítios de ação por meio de proteínas fluorescentes. Foram incluídos também exemplos do uso de CRISPR/Cas na edição genômica de plantas e patógenos visando ao aumento da resistência de plantas a fungos, bactérias, vírus e nematoides.

PALAVRAS-CHAVE: edição genômica, fitopatógenos, nocaute, resistência

\section{INTRODUÇÃO}

O cenário agrícola atual envolve grandes desafios devido à crescente demanda por alimento, falta de terras cultiváveis para ampliar as áreas produtivas, escassez de recursos hídricos e bruscas mudanças climáticas. Além disso, a necessidade de plantios em monocultura e em larga escala, bem como as constantes aplicações de produtos químicos favorecem a ocorrência de doenças e a seleção de patógenos resistentes. Existe, ainda, o risco permanente de epidemias súbitas que ameaçam a estabilidade dos agroecossistemas e a biodiversidade (CORREDOR-MORENO \& SAUNDERS 2020). Este risco está associado às mudanças climáticas e globalização do comércio de produtos vegetais que facilitam a introdução de patógenos em novas áreas e o aumento de variabilidade genética dos fitopatógenos em locais já estabelecidos (MATIC et al. 2019, CORREDOR-MORENO \& SAUNDERS 2020). Diante deste cenário complexo, torna-se necessária a busca por soluções inovadoras e sustentáveis que viabilizem o aumento da produtividade e a redução de perdas na agricultura (CHEN et al. 2019).

Entre as boas práticas agrícolas, uma alternativa é o desenvolvimento e uso de cultivares com características agronômicas superiores, como maior

${ }^{1}$ Departamento de Fitopatologia, Universidade de Brasília, Brasília, Distrito Federal, 70910-900, Brasil. ${ }^{2}$ Embrapa Agroenergia. Parque Estação Biológica, Av. W3 Norte (final), Asa Norte, 70770-901, Brasília, Distrito Federal, Brasil. ${ }^{3}$ National Coffee Research Center - CENICAFÉ, Colombian Coffee Growers Federation - FNC, 17000-9, Manizales, Caldas, Colombia. *Email: thais.santiago@unb.br 
tolerância e resistência a um ou mais fitopatógenos. O melhoramento genético convencional e a indução de mutações em plantas têm sido amplamente utilizados para obtenção de plantas resistentes a fitopatógenos (CHEN et al. 2019). No entanto, essas estratégias são limitadas, pois a obtenção das características de interesse é, na maioria das vezes, dificultada por fatores como: ocorrência de mutações, alta ploidia de algumas culturas, limitada variabilidade genética, ausência de conhecimento do(s) gene(s) responsável(eis) pelo fenótipo de interesse e o longo ciclo vegetativo de algumas plantas (SCHEBEN et al. 2017). Avanços biotecnológicos têm permitido a obtenção de genótipos desejáveis em menor tempo e com baixo custo, comparadas com o meIhoramento genético convencional e uso de agentes mutagênicos.

A transformação genética via transgenia ou cisgenia, que consiste em inserir, respectivamente, gene(s) exógeno(s) ou da própria espécie ou gênero em cultivares elite, contribuiu para que houvesse avanços importantes no melhoramento genético, especialmente para resistência a fitopatógenos. Entretanto, o receio da população em consumir alimentos derivados de organismos geneticamente modificados (OGM) e a regulamentação rigorosa para o desenvolvimento e aprovação de cultivares geneticamente modificadas (GM), vêm impulsionando o uso de tecnologias não-transgênicas (SCHEBEN et al. 2017). Além disso, a associação entre os recentes avanços na área genômica e os estudos de enzimas nucleases permitiu o surgimento de ferramentas de edição genômica sítio-dirigidas, não envolvendo a inserção de sequências exógenas no genoma das plantas.

Diferentes técnicas de edição genômica utilizam nucleases quiméricas capazes de induzir a clivagem do DNA. A primeira nuclease sítio específico engenheirada com efetiva capacidade de realizar edição em genomas contém dois arranjos, um composto pela enzima Fokl com domínio de clivagem inespecífico, que quebra a dupla fita de DNA, e outro contendo um arranjo de repetições de dedos de zinco Cys2-His2, responsável pelo reconhecimento e ligação na região alvo do DNA. Esta primeira molécula quimérica engenheirada ficou conhecida como nuclease dedo de zinco (Zinc Finger Nuclease, ZFN) (BIBIKOVA et al. 2002). Posteriormente, uma nova tecnologia utilizando efetores do tipo ativador trans- cricional foi desenvolvida e nomeada como nuclease com efetores do tipo ativador transcricional (Transcription Activator Like Effector Nuclease, TALEN), originalmente descoberta em bactérias fitopatogênicas do gênero Xanthomonas. O sistema TALEN também envolve o uso da enzima Fokl porém, a estrutura de ligação ao DNA é composta por 13-30 domínios residuais de aminoácidos em série e diresíduos variáveis (Repeat Variable Diresidue, RDV), os quais atuam no reconhecimento e modificação de alvos específicos no genoma (CHRISTIAN et al. 2010).

As técnicas ZFN e TALEN foram utilizadas com sucesso na edição genômica de um número variado de genes em diferentes espécies vegetais (CHEN et al. 2019, SATHEESH et al. 2019). Contudo, ambas as técnicas exigem o redesenho da proteína quimérica e do RDV para cada alvo novo a ser editado, o que demanda tempo e tem um custo elevado. Assim, tornou-se necessária a busca por alternativas de edição genômica e uma nova tecnologia vem se destacando - o sistema CRISPR/Cas (Clustered Regularly Interspaced Short Palindromic Repeats/ CRISPR-associated proteins). Essa tecnologia teve origem na adaptação de um mecanismo natural de defesa de bactérias e archaea contra bacteriofagos e plasmídeos (BARRANGOU et al. 2007). A técnica foi otimizada experimentalmente, sendo necessários apenas dois componentes para seu funcionamento: um RNA guia (gRNA) e uma nuclease Cas (JINECK et al. 2012). O gRNA permite o direcionamento da enzima Cas que, por sua vez, cliva um alvo específico no DNA. A quebra da fita dupla de DNA desencadeia um mecanismo natural de reparo celular, resultando na edição genômica propriamente dita (PAWELCZAK et al. 2018).

A tecnologia CRISPR/Cas vem sendo utilizada em plantas desde 2013, principalmente para a edição genômica (FENG et al. 2013, Ll et al. 2013, NEKRASOV et al. 2013, SHAN et al. 2013, XIE \& YANG 2013). Especificamente na Fitopatologia, o sistema CRISPR/Cas tornou-se uma excelente alternativa para explorar as interações planta-patógeno por meio de pesquisas básicas na área da genômica funcional e desenvolvimento de cultivares resistentes a fitopatógenos (e.g. pelo nocaute de genes de suscetibilidade da planta hospedeira ou genes de virulência de patógenos) (GOSAVI et al. 2020). Essas abordagens têm como objetivo o melhoramento genético de plantas para o controle de doenças. 


\section{CRISPR/CAS NO SISTEMA IMUNE DE PROCARIOTOS}

As sequências palindrômicas curtas intercaladas regularmente nos genomas procariotos, que deram nome ao sistema CRISPR, foram observadas pela primeira vez em 1987, quando Ishino e colaboradores analisaram o gene iap de Escherichia coli, responsável pela conversão enzimática da fosfatase alcalina. No entanto, investigações aprofundadas sobre essa descoberta ocorreram apenas quando diferentes grupos de pesquisadores descreveram a mesma sequência em outros gêneros de bactérias e archaea (ISHINO et al. 1987, MOJICA et al. 2000). As referidas sequências foram inicialmente denominadas como repetições curtas regularmente espaçadas (Short Regularly Spaced Repeats, SRSR) (MOJICA et al. 2000), mas, em 2002, a nomenclatura foi modificada e padronizada como CRISPR (JANSEN et al. 2002), termo utilizado pela comunidade científica até os dias atuais.

A descoberta da origem da região CRISPR só foi possível em decorrência do aumento considerável no número de genomas sequenciados de diferentes organismos, a partir dos quais desvendou-se a origem das regiões espaçadoras do locus CRISPR, sendo estas provenientes de sequências extracromossomais de plasmídeos e vírus. Com base nesta descoberta, sugeriu-se que as sequências repetidas poderiam estar envolvidas no sistema imune adaptativo de procariotos (BOLOTIN et al. 2005, MOJICA et al. 2005, POURCEL et al. 2005). Posteriormente, identificaram-se quatro genes nas proximidades da estrutura CRISPR, que foram denominados de família Cas. Como os genes dessa família são responsáveis por codificar polimerases, helicases e endonucleases, surgiu a hipótese de que estes genes estariam envolvidos no funcionamento e expressão do locus CRISPR, o qual passou a ser chamado, a partir de então, como locus CRISPR/Cas (JANSEN et al. 2002).

A função do locus CRISPR/Cas, como mecanismo da imunidade adquirida em procariotos, foi comprovada experimentalmente em Streptococcus thermophilus (BARRANGOU et al. 2007). Nesse trabalho, os autores verificaram que o processo de imunização ocorreu devido à integração de pequenos fragmentos de 24 a 48 pb do DNA exógeno invasor no ínicio da região CRISPR do cromossomo bacteriano, passando a serem chamados de espaçadores (spacers), os quais funcionam como uma "memória de defesa" direcionada contra invasões subsequen- tes pelo organismo correspondente. O sistema torna-se funcional a partir da interação de dois componentes principais: (i) o locus CRISPR, que contém os espaçadores provenientes do DNA exógeno intercalados em repetições palindrômicas curtas da própria bactéria; e (ii) um grupo de genes que flanqueiam o locus CRISPR e codificam proteínas Cas, responsáveis por clivar o DNA exógeno quando há uma nova infecção pelo mesmo invasor (GARNEAU et al. 2010, MARRAFFINI 2015).

De forma ampla, a resposta imune bacteriana baseada em CRISPR pode ser dividida em três fases: adaptação, expressão e interferência. Na adaptação, o organismo invasor é reconhecido e processado por um complexo de proteínas Cas, que clivam a sua sequência de DNA (denominada espaçador-precursor ou protospacer), gerando o fragmento que se tornará um novo espaçador após ser integrado ao locus CRISPR (DEVEAU et al. 2008, MAKAROVA et al. 2020). O reconhecimento e a ligação desse complexo proteico ao DNA-alvo ocorre por meio de uma sequência pequena e conservada de 2 a $5 \mathrm{pb}$ localizada próxima ao protospacer, conhecida como PAM (Protospacer Adjacent Motif) (DEVEAU et al. 2010, MAKAROVA et al. 2020). Em seguida, na fase de expressão, ocorre a transcrição do locus CRISPR, resultando em um longo precursor de RNA CRISPR (pré-crRNA). O transativador de crRNA (tracrRNA), outro componente envolvido na maquinaria, apresenta complementaridade parcial ao pré-crRNA, e a hibridização desses dois componentes (híbrido crRNA-tracrRNA) leva à clivagem do pré-crRNA pela ação, principalmente, de enzimas RNase III, resultando na formação de moléculas de RNA CRISPR maduras (crRNA) (HORVATH \& BARRANGOU 2010). Cada crRNA é composto por uma sequência espaçadora específica e uma sequência repetida do locus CRISPR (DELTCHEVA et al. 2011). Por fim, na etapa de interferência, o complexo efetor do sistema CRISPR é formado pela molécula híbrida crRNA-tracrRNA associada à nuclease Cas, que é direcionada ao DNA invasor por complementaridade à sequência espaçadora presente no crRNA. Do ponto de vista estrutural, a porção $5^{\prime}$ do tracrRNA se hibridiza à porção terminal $3^{\prime}$ do crRNA, deixando as outras extremidades livres. A extremidade $5^{\prime}$ do crRNA atua no reconhecimento do DNA-alvo e a porção 3' do tracrRNA interage com a Cas. A clivagem e inativação do DNA exógeno pela nuclease Cas interfere na replicação 
viral ou na atividade do plasmídeo, impedindo o sucesso da invasão (GARNEAU et al. 2010) (Figura 1).

O sistema CRISPR/Cas procariótico tem características peculiares e importantes do ponto de vista adaptativo, como a capacidade de perder ou adquirir novos espaçadores, permitindo que sua resposta seja dinâmica e acompanhe a evolução do invasor, além da possibilidade de ser transferido hereditariamente para as células filhas (BHAYA et al. 2011).

\section{CLASSIFICAÇÃO DO SISTEMA CRISPR}

Atualmente, há diferentes mecanismos CRIS$\mathrm{PR} /$ Cas em procariotos, subdivididos em duas classes, seis tipos e 33 subtipos, de acordo com a natureza do complexo efetor e enzimas Cas envolvidas. A classe 1 inclui os tipos I, III e IV, os quais utilizam efetores formados por múltiplas Cas, algumas das quais geram complexos de ligação ao crRNA, como o complexo associado a CRISPR para defesa antiviral (CRISPR-Associated Complex for Antiviral Defense, CASCADE) (MAKAROVA et al. 2020). Nos três tipos da classe 1 , ocorre a atuação de proteínas denomi- nadas como Repeat-Associated Mysterious Protein (RAMP), um subconjunto de proteínas Cas, destacando-se Cas5 e Cas7, que possuem motifs de reconhecimento de RNA (RNA Recognition Motif, RRM) e podem ter atividade de ribonuclease envolvida na maturação do crRNA. A RAMP Cas6, também presente na classe 1 , é uma RNase responsável pelo processamento do pré-crRNA e pode ou não estar associada ao complexo efetor (BHAYA et al. 2011, MAKAROVA et al. 2020). O sistema tipo I é dividido em nove subtipos e possui como componente chave a Cas3, enzima com domínios de helicase e nuclease HD (substrato de DNA fita simples) necessária para a clivagem do material genético exógeno (BHAYA et al. 2011, SINKUNAS et al. 2011, MAKAROVA et al. 2020). O tipo III, com seis subtipos, inclui a Cas10 fusionada a um domínio diferente de nuclease HD, sendo esta enzima responsável pelo processamento do crRNA e clivagem do DNA-alvo dependente da sua transcrição (ANANTHARAMAN et al. 2010, MAKAROVA et al. 2020). O sistema tipo IV é dividido em três subtipos que ainda não possuem proteínas Cas conhecidas envolvidas nas fases de adaptação

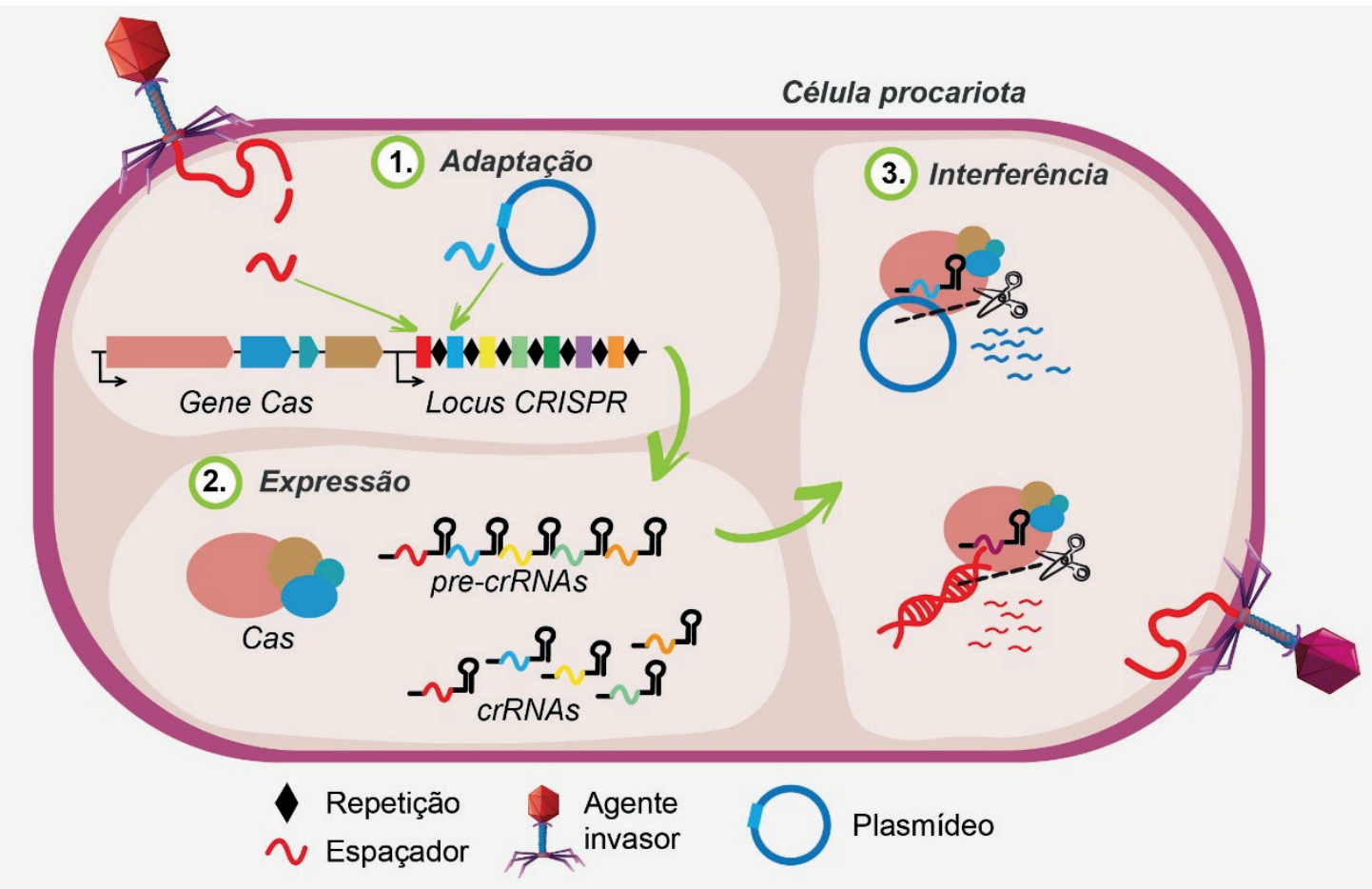

Figura 1. Resposta do sistema imune adaptativo CRISPR/Cas em procariotos. Os três estágios do sistema CRISPR/Cas estão representados esquematicamente: adaptação, expressão e interferência. Durante a fase de adaptação, novos espaçadores podem ser incorporados ao início do locus CRISPR com a invasão do vírus ou plasmídeos a célula procariota. Já na fase de expressão, ocorre a transcrição da matriz CRISPR e o processamento do pré-crRNA para a formação do crRNA. Consequentemente, na fase de interferência, as moléculas invasoras são reconhecidas e clivadas pela associação do crRNA e da nuclease Cas devido a uma reinfecção ou a invasão de um organismo com sequências correspondentes a uma sequência do espaçador CRISPR. 
e clivagem do alvo, e suas funções ainda não foram demonstradas experimentalmente (ÖZCAN et al. 2019, MAKAROVA et al. 2020).

Diferente da classe 1 , que envolve complexos efetores com múltiplas Cas, a classe 2 possui uma única proteína efetora grande (Cas9, Cas12 ou Cas13). Esta classe é dividida nos tipos II, V e VI que se diferem quanto aos mecanismos de processamento do pré-crRNA (CHYOU \& BROWN 2019, FAURE et al. 2019, MAKAROVA et al. 2020). O sistema tipo Il é constituído por três subtipos e engloba uma enzima não-Cas, a RNase III, para processamento do pré-crRNA, além de ser caracterizado pela presença da Cas9, uma enzima que executa diversas funções, incluindo a degradação do DNA invasor (GARNEAU et al. 2010, MAKAROVA et al. 2020). O sistema tipo $\checkmark$ é mais diversificado (10 subtipos) e inclui a Cas12, enquanto o tipo VI, com cinco subtipos, envolve a Cas13. Em CRISPR tipo VI e alguns subtipos V, essas grandes proteínas Cas (Cas12 e Cas13), além de participarem do complexo efetor na fase de interferência, também desempenham atividade de RNase para processamento do pré-crRNA (EAST-SELETSKY et al. 2016, FONFARA et al. 2016, LIU et al. 2017, MAKAROVA et al. 2020).

\section{PROTEÍNAS CAS}

As proteínas Cas são diversificadas e multifuncionais, podendo conter domínios de helicase, nuclease, polimerase e de ligação a moléculas de RNA (MAKAROVA et al. 2020). Cas1 e Cas2, enzimas envolvidas na fase de aquisição de novos espaçadores, são consideradas universais, pois atuam nos seis tipos das duas classes do sistema CRISPR (BHAYA et al. 2011, MAKAROVA et al. 2020). Como mencionado anteriormente (vide tópico "Classificação do sistema CRISPR"), há outras enzimas Cas envolvidas nas demais fases do sistema, especialmente na etapa de interferência em que ocorre a formação do complexo efetor. Porém, a seguir, serão detalhadas somente as enzimas Cas9 e Cas12, caracterizadas como as duas proteínas mais utilizadas como ferramentas biotecnológicas para a edição de genomas.

A Cas9 é utilizada na maioria dos estudos e foi a primeira enzima a ser descrita como ferramenta para a edição genômica (RAN et al. 2013). Trata-se de uma proteína de 160 kDa que possui estrutura bilobulada, formada por um lobo de reconhecimento alfa-helicoidal (REC) e outro com atividade nucleási- ca (NUC), este último contendo o domínio catalítico $\mathrm{HNH}$ na região central e RuvC na região $\mathrm{N}$-terminal (GASIUNAS et al. 2012). No sistema CRISPR/Cas9, o híbrido crRNA-tracrRNA guia a Cas9 para clivagem de qualquer DNA contendo a sequência-alvo correspondente e adjacente ao PAM (GARNEAU et al. 2010, CHYOU \& BROWN 2019, FAURE et al. 2019). A partir desse reconhecimento, a enzima processa a fita dupla de DNA (dsDNA) especificamente no terceiro nucleotídeo a montante do sítio PAM, através de seus dois domínios nucleásicos: $\mathrm{HNH}$ cliva a fita de DNA complementar à sequência espaçadora presente no complexo efetor (fita-alvo), enquanto RuvC é responsável pela clivagem da fita de DNA não complementar (fita não-alvo) (GASIUNAS et al. 2012, JIANG \& DOUDNA 2017). O sítio PAM reconhecido pela Cas9 é rico em $\mathrm{G}$ (geralmente $5^{\prime}-\mathrm{NGG}-3^{\prime}$ ), e as clivagens realizadas por esta enzima resultam em sequências com extremidades abruptas (YANG \& PATEL 2019).

A proteína originalmente descrita como Cpf1, e atualmente conhecida como Cas12a, também tem sido utilizada em edições genômicas como uma alternativa à Cas9, isso porque essa classe de enzimas tem origem evolutiva e estrutural diferentes, resultando em mecanismos moleculares distintos (SWARTS \& JINEK 2018). A Cas12a possui dois sítios de domínio RuvC e nenhum HNH. Assim, no sistema CRISPR/Cas12a, acredita-se que um único sítio ativo de RuvC cliva ambas as fitas do DNA-alvo (SWARTS et al. 2017). Diferentemente da Cas9, a Cas12a não requer tracrRNA, e o local de clivagem desta enzima ocorre longe do sítio PAM, cerca de 23 nucleotídeos distante na fita não-alvo e 18 nucleotídeos de distância na fita-alvo (ZETSCHE et al. 2015). Além disso, o complexo Cas12a-crRNA reconhece o PAM rico em T (5'-TTTN-3'), levando à clivagem de sítios escalonados e gerando sequências com extremidades coesivas (ZETSCHE et al. 2015, FONFARA et al. 2016).

\section{ADAPTAÇÃO DO SISTEMA CRISPR/CAS PARA A EDI- ÇÃO GENÔMICA}

No processo natural de imunidade bacteriana, as proteínas Cas são ativadas e direcionadas aos seus alvos mediante ação de duas moléculas de RNA que atuam cooperativamente, a crRNA e tracrRNA (vide tópico "CRISPR/Cas no sistema imune de bactérias"). Para facilitar a utilização desse sistema em 
laboratório como ferramenta de edição genômica, pesquisadores desenvolveram uma molécula quimérica denominada Single Guide RNA (sgRNA ou gRNA), formada pela fusão de crRNA e tracrRNA (JINEK et al. 2012). Trata-se de uma molécula de fita simples de $\sim 20$ nucleotídeos que contém uma sequência-guia (o crRNA com espaçador complementar ao DNA-alvo localizado na extremidade $5^{\prime}$ ) fusionada ao tracrRNA (extremidade 3') (Figura 2). Neste caso, o tracrRNA corresponde a uma sequência universal e constante de $\sim 80$ pb no gRNA, chamada de RNA scaffold. O RNA scaffold possui uma estrutura secundária em forma de grampo necessária para o reconhecimento e interação com a enzima Cas, e outra estrutura adicional que sinaliza a finalização da transcrição (JINEK et al. 2012, BORTESI \& FISCHER 2015). O gRNA pode ser utilizado, portanto, para edição de diferentes alvos genômicos, sendo necessária apenas a alteração da sequência guia.

O sistema CRISPR/Cas9 de Streptococcus pyogenes (SpCas9) foi o primeiro sistema adaptado para edição de genomas eucariotos por meio de RNA programável (JINEK et al. 2012). Neste sistema, a Cas9 reconhece o gRNA, forma o complexo Cas9-gRNA e percorre a fita dupla do DNA-alvo até encontrar o sítio PAM. Em seguida, o domínio helicase da Cas 9 promove a abertura do dsDNA, permitindo o pareamento entre o gRNA e o DNA-alvo; e, por fim, ocorre a clivagem do DNA (CONG et al. 2013, JIANG et al. 2015). Comparado a outras ferramen- tas de edição sítio-específica, o sistema CRISPR/Cas destaca-se por ser uma técnica simples, de baixo custo e alta eficiência (CHEN et al. 2019). A clivagem do DNA-alvo leva ao recrutamento dos mecanismos de reparo de DNA do próprio organismo, resultando na edição pontual do genoma pelos mecanismos de reparo NHEJ ou HDR (SATHEESH et al. 2019).

\section{MECANISMOS DE REPARO NHEJ e HDR}

Durante os ciclos celulares de eucariotos, as moléculas de DNA podem sofrer diferentes danos, como a quebra da fita dupla (Double-Strand Break, DSB), ocasionada pelo próprio metabolismo das células ou por fatores externos. DSB é um tipo de dano importante que pode levar à apoptose ou senescência (VIEIRA et al. 2016), motivo pelo qual também existem mecanismos naturais de reparo celular. Após DSB, o reparo do dsDNA é realizado por duas vias principais: junção de extremidades não-homólogas (Non-Homologous End Joining, NHEJ) ou direcionado por homologia (Homology-Directed Repair, HDR) (SATHEESH et al. 2019). Do ponto de vista biotecnológico, os pesquisadores baseiam-se na ativação destes dois mecanismos de reparo do DNA para que, de fato, seja realizada a edição genômica.

NHEJ é o principal mecanismo de reparo de células eucarióticas, ocorrendo em todas as etapas do ciclo celular (PUCHTA 2005, MAO et al. 2008). Este mecanismo não se baseia em homologia de sequências, isto é, ele reúne as duas pontas de DNA a.

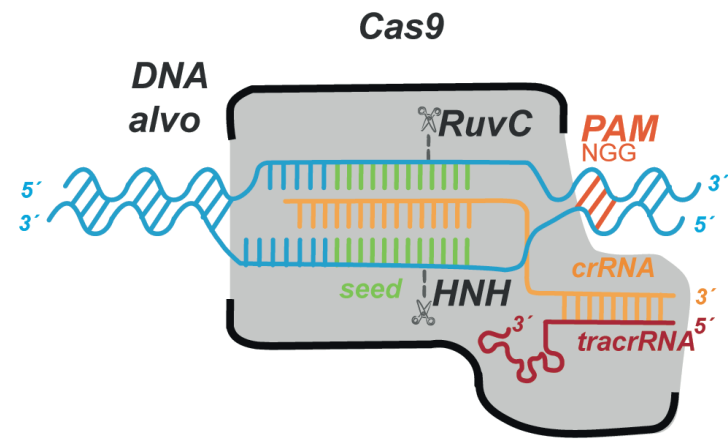

b.

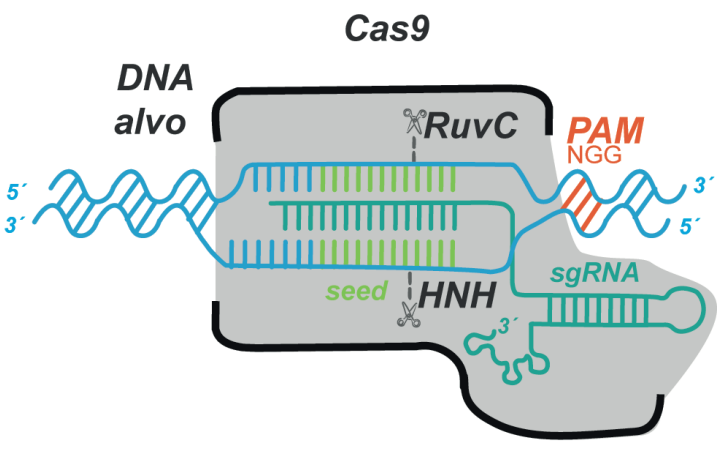

Figura 2. Representação esquemática da adaptação do sistema CRISPR/Cas para a edição de genomas utilizando apenas dois componentes. (A) No sistema natural, a nuclease Cas do sistema CRISPR/Cas de Streptococcus pyogenes (SpCas9) é direcionada ao DNA correspondente contendo uma sequência PAM adjacente pelo crRNA e tracrRNA. Posteriormente, a dupla fita do DNA invasor é clivada pelos domínios RuvC e HNH da nuclease Cas. (B) No sistema adaptado de dois componentes, um gRNA quimérico composto por um único componente, associando crRNA e tracrRNA em uma única sequência, foi criado para guiar e associar a Cas. 
por meio de eventos não dependentes de homologia entre as extremidades. Resumidamente, a via NHEJ é dividida em três etapas: reconhecimento da DSB, processamento do DNA e ligação das fitas (YANG et al. 2016). Na primeira, ocorre o reconhecimento da DSB pelas proteínas Ku70 e Ku80, que funcionam como âncoras para outras proteínas importantes durante a NHEJ, tais como a subunidade catalítica da proteína quinase dependente de DNA (DNA-PKcs), proteína de reparo de raios- $X$ transversal complementar 4 (XRCC4), fator tipo XLF e DNA-ligase IV (Lig4), todas elas essenciais para as etapas posteriores de processamento e ligação (TAMURA et al. 2002, DAVIS et al. 2014). Como a maioria das DSBs possuem extremidades incompatíveis que impedem a ligação direta das fitas, o DNA precisa passar pela fase de processamento por diversas enzimas, resultando em extremidades 5' ou 3' com micro-homologia compatíveis (LIEBER 2010). Por fim, ocorre a religação da fita dupla de DNA pela ação da Lig4 e do complexo XRCC4-XLF, que é o principal fator envolvido na estabilização do processo de ligação (ANDRES et al. 2012).

A via NHEJ é propensa a erros, gerando mutações dos tipos inserção ou deleção (indel) e substituição no sítio de ligação das fitas de DNA ou em sua proximidade. Essas mutações podem comprometer a funcionalidade do gene, resultando em expressão gênica parcial, totalmente interrompida e proteína não-funcional. O mecanismo de reparo tipo NHEJ frequentemente resulta em nocaute (inativação) do gene-alvo (BORTESI \& FISCHER 2015, CUI et al. 2019). Pela facilidade com que o sistema CRISPR/Cas cliva diferentes locais com uma única proteína Cas, é possível inativar vários genes simultaneamente via NHEJ com o uso de diferentes gRNAs (SALSMAN \& DELLAIRE 2017).

Diferente do mecanismo NHEJ, HDR requer uma fita-molde para reparar a sequência de dsDNA clivada, um elemento chave para a edição genômica via recombinação homóloga (Homologous Recombination, HR). HDR ocorre naturalmente nas células utilizando a fita de DNA da cromátide-irmã como molde, mas é possível fornecer uma sequência molde exógena, chamada de DNA doador, que deve possuir homologia com ambas as extremidades resultantes da clivagem (HEYER et al. 2010, SALSMAN \& DELLAIRE 2017). Contudo, a via HDR ocorre em baixa frequência durante os ciclos celulares, especi- ficamente nas fases S e G2 da interfase, quando as cromátides-irmãs estão disponíveis para serem utilizadas no reparo (VU et al. 2019).

Experimentalmente, CRISPR/Cas é modificado para via HDR, envolvendo três elementos exógenos introduzidos na célula: a enzima Cas, o gRNA e o DNA doador (componente chave de HDR). Após a clivagem do dsDNA pela Cas, a via HDR recruta uma série de complexos proteicos para reparar esse dano usando como molde o DNA doador. Comparado à NHEJ, esta forma de reparo é menos propensa a erros, sendo um sistema de alta fidelidade que permite a inserção ou edição de sequências de interesse na região-alvo editada (CHEN et al. 2019, ANZALONE et al. 2020). A edição via HDR pode ser utilizada para troca de bases específicas no DNA, promovendo alterações pontuais na sequência de nucleotídeos ou para substituição de sequências por meio da deleção seguida de inserção (HUANG \& PUCHTA 2019). Entretanto, em plantas, o sistema HDR tende a ser complexo e com menor eficiência de alteração genética (NISHIZAWA-YOKOI et al. 2014), dependendo de estratégias e do tamanho do DNA doador para aumentar a sua eficácia na célula (CERMAK et al. 2015, BUTT et al. 2017, GIL-HUMANES et al. 2017) (Figura 3).

\section{ESTRATÉGIAS PARA AUMENTAR A ESPECIFICIDADE E EFETIVIDADE DA EDIÇÃO GENÔMICA}

A eficiência e contribuição do sistema CRIS$\mathrm{PR} /$ Cas na edição de genomas são incontestáveis. Porém, o processo de clivagem fora do alvo de interesse (off-target) pela proteína Cas é um fator preocupante. Essta preocupação acentuou-se após Schaefer e colaboradores, em 2017, detectarem centenas de mutações indesejadas causadas pelo sistema CRISPR/Cas. A princípio, acreditava-se que o pareamento de bases tipo Watson-Crick de uma sequência de 20 pb seria suficiente para conferir a especificidade desejada. Contudo, sabe-se, hoje, que a homologia de 8 a 12 pb na região 3' do gRNA, também conhecida como região seed, permite o reconhecimento e clivagem da sequência-alvo. Além disso, o mau pareamento (mismatches) de bases na região distal do sítio PAM, assim como sequências de DNA de alta homologia contendo uma base extra (DNA bulge) ou a falta de uma base (gRNA bulge), possibilitam que ocorra a clivagem de regiões off-targets (LIN et al. 2014). 


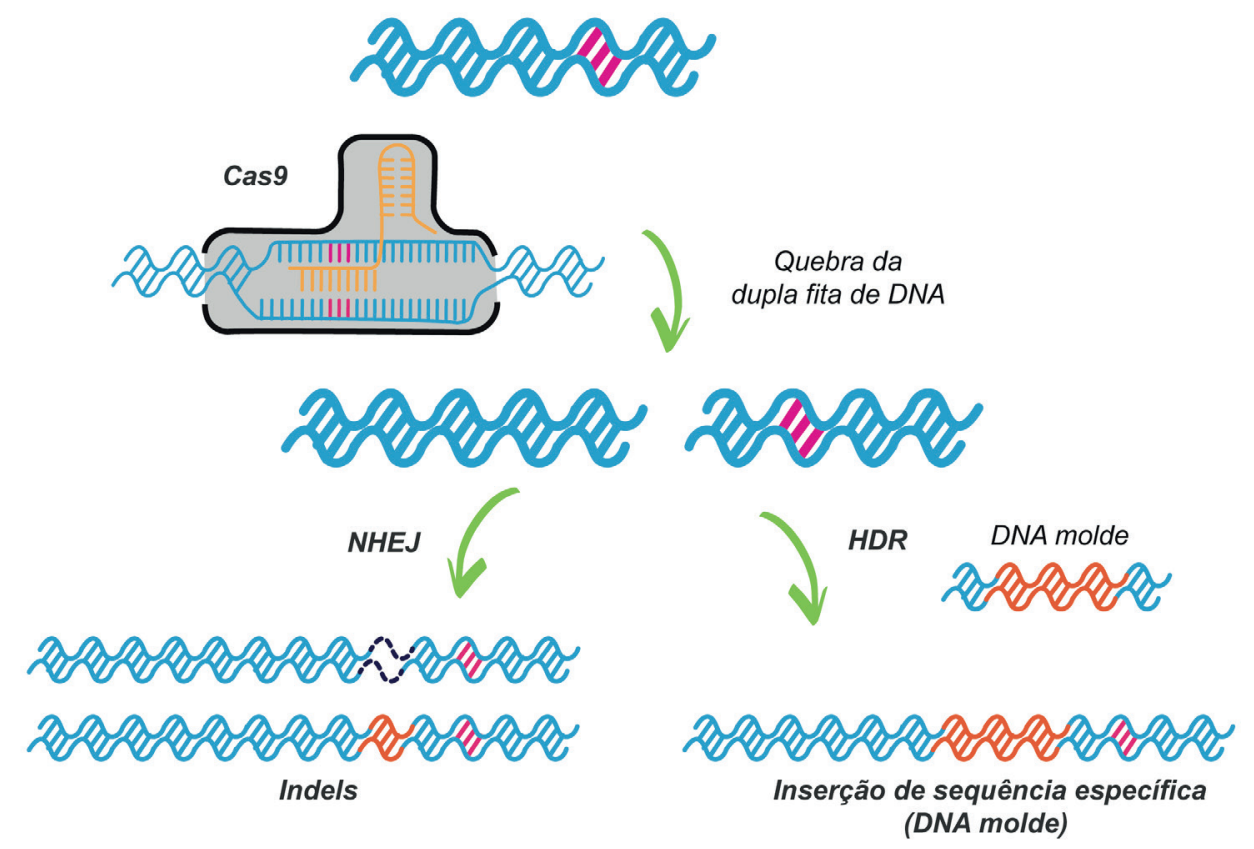

Figura 3. Representação esquemática dos mecanismos de reparo do DNA fita dupla pela junção de extremidades não homólogas (NHEJ) e por recombinação homóloga direcionado por homologia (HDR). No mecanismo de reparo tipo NHEJ, a quebra da dupla fita de DNA pode resultar na inserção ou deleção de nucleotídeos que pode levar a uma mudança no quadro de leitura da proteína e/ou a um códon de parada precoce. No HDR, um DNA doador é usado como molde para corrigir a quebra do DNA. Esse último reparo é possível a adição de um fragmento de DNA ou alteração de uma ou mais base na sequência alvo.

Na tentativa de conter os efeitos off-targets pelo sistema CRISPR/Cas, diversos esforços vêm sendo realizados envolvendo a utilização de ferramentas in silico para seleção de gRNA e a otimização de proteínas Cas nativas. Alternativas promissoras vêm sendo desenvolvidas, destacando-se: (i) indução de corte do DNA com o uso de heterodímeros por meio de nickases ou fusão da proteína Fokl à Cas inativa; (ii) proteínas ortólogas a Cas9 ou novas proteínas CRISPR com maior especificidade; (iii) uso de enzimas Cas racionalmente engenheiradas; e (iv) truncamento ou alteração da sequência da molécula de RNA scaffold no gRNA (LIU et al. 2020).

O primeiro passo para a utilização de uma nickase é a geração de uma nuclease mutante, geralmente a Cas9. A mutação pontual deve ocorrer em um dos domínios catalíticos da enzima, na posição H840A do domínio HNH ou D10A de RuvC, levando à formação de uma nickase capaz de clivar apenas uma das fitas do DNA (BORTESI \& FISCHER 2015). Logo, para que ocorra o nocaute do gene de interesse, é preciso que um par de nickase e gRNA com complementaridade à sequência-alvo sejam utilizados. Como consequência, têm-se a necessidade de aumento do número de bases a serem reconhecidas para a clivagem, resultando na redução de off-targets, maior especificidade e fidelidade do reparo (BORTESI \& FISCHER 2015).

Outra estratégia envolvendo mutantes Cas é a utilização de enzimas cataliticamente inativas, com os domínios HNH e RuvC mutados, e adição de uma nuclease Fokl. A Cas inativa é denominada como dead Cas, também conhecida como dCas. Fokl é uma enzima originalmente descoberta na bactéria Flavobacterium okeanokoites contendo dois domínios, responsável pela ligação e clivagem do DNA nas posições $\mathrm{N}$ - e C-terminal, respectivamente ( $\mathrm{HI}$ ROYUKI \& SUSUMU 1981). Essa nuclease tem atividade catalítica apenas com a formação de dímero, ou seja, é necessária a utilização de duas Fokl para que ocorra a clivagem de uma fita de DNA, resultando em uma DSB. Observou-se que a fusão de Fokl à duas dCas aumentou em mais de 100 vezes a especificidade do sistema quando comparada à Cas9 nativa (TSAl et al. 2014).

O aumento da especificidade do sistema CRISPR também foi observado com o uso de nucleases guiadas por gRNA com comprimento que difere 
de 20 pb. A adição de duas guaninas na região $5^{\prime}$ do gRNA de 20 pb (GG-gRNA) e o uso de gRNA truncado de $17 \mathrm{pb}$ de comprimento (tru-gRNA) melhoram a performance na redução de off-targets (FU et al. 2014). Embora seja mais eficiente em minimizar a chance de efeito fora do alvo, a utilização de GG-gRNA reduz sua efetividade no sítio-alvo (on-target), diferente do tru-gRNA que mantém a mesma eficiência. Acredita-se que a redução dos off-targets causados por tru-gRNA se deve à remoção dos nucleotídeos promíscuos na região 5' do gRNA (KUSCU et al. 2014).

Variantes naturais ou engenheiradas de Cas9 têm se mostrado funcionalmente eficientes na redução de off-targets, apresentando como vantagem, por exemplo, o reconhecimento da região PAM mais restritiva do que a 5'-NGG-3' reconhecida pela SpCas9 (MENG et al. 2018). Essa estratégia aumenta a quantidade de bases específicas reconhecidas para a clivagem, reduzindo os efeitos em sequências homólogas presentes em outros locais do genoma (BORTESI \& FISCHER 2015). Um exemplo é a descoberta de diferentes enzimas, como a Cas12 (vide tópico "Proteínas Cas"), que são capazes de reconhecer sequências PAM ricas em timina (5'-TTTN-3'). Além disso, o corte da Cas12 resulta em extremidades coesivas, aumentando a taxa de eficiência na via HDR (ZAIDI et al. 2017). O reconhecimento de um maior número de bases na região PAM leva à redução de off-targets, principalmente em genomas com maior conteúdo de GC (CHEN et al. 2019), mas, por outro lado, limita o número de sítios de clivagem no alvo. Para resolver esste problema, várias Cas9 foram engenheiradas visando reconhecer sítios PAM diferentes, tais como: VQR-Cas9, EQR-Cas9, VRER-Cas9, SaKKH-Cas9, (KLEINSTIVER et al. 2015), xCas9 (HAMADA et al. 2017) e SpCas9-NG (NISHIMASU et al. 2018).

A edição programada de bases específicas vem se mostrando uma opção interessante e mais efetiva para a substituição do mecanismo HDR (GAUDELLI et al. 2017). A edição de bases é um mecanismo que permite induzir alterações específicas na sequência-alvo de maneira mais precisa e eficiente do que via HDR, sem ser necessária a presença de um DNA doador. Para que isso ocorra, uma citosina desaminase e um inibidor (UGI) de uracil DNA glicosilase (UDG) são ligados a dCas9. Esse sistema é denominado editor de base citosina (Cytosine $\mathrm{Ba}$ -
se-Editor, $\mathrm{CBE})$, cuja enzima é capaz de converter citosina ou guanina em uracila diretamente na sequência de interesse, que, por sua vez, é substituída por uma timina ou adenina na replicação do DNA, respectivamente (KOMOR et al. 2016).

Outros editores de bases ortólogos ao CBE foram descritos e utilizados em plantas, a exemplo: (i) editor de bases de adenina (Adenine Base Editors, $A B E)$, o qual permite a conversão de adenina em guanina (GAUDELLI et al. 2017); (ii) duplo editor de bases capaz de substituir citosina e adenina usando um único gRNA, denominado STEME (Saturated Targeted Endogenous Mutagenesis Editor); e (iii) AFIDs (APOBEC-Cas9 Fusion-Induced Deletion Systems), editor que promove múltiplas deleções de forma precisa devido à presença de citidina deaminase, Cas9, UDG e AP liase.

Embora a técnica de edição de bases represente uma inovação na engenharia genética, ela não é capaz de converter todos os 12 tipos de alterações de bases, nem mesmo inserir ou eliminar fragmentos do genoma (ANZALONE et al. 2019). Para solucionar esse problema, o mesmo laboratório responsável pelo desenvolvimento da técnica de edição de base, criou a técnica de prime editing. De forma simplificada, a técnica do prime editing diferencia-se pela incorporação de um novo domínio catalítico associado a nickase, um o domínio da transcriptase reversa, juntamente com um guia de edição denominado pegRNA. O pegRNA tem função de guiar a nickase para o sítio de edição e abrigar a sequência que será alterada no DNA. A nickase irá cortar a fita não-alvo, expondo o grupo hidroxila 3', sendo a transcriptase reversa capaz de inserir as alterações de forma personalizada na sequência do DNA usando as informações presentes no pegRNA (MARZEC et al. 2020). Esses métodos estão sendo cada vez mais utilizados em substituição ao HDR por serem mais robustos e apresentarem menores chances de alterações errôneas no DNA (CHEN et al. 2019).

\section{APLICAÇÕES ADICIONAIS DO SISTEMA CRISPR/CAS}

Atualmente, o sistema CRISPR vem sendo utilizado não apenas para edições genômicas, mas também para a marcação de DNA (DREISSIG et al. 2017), alteração de expressão genética (KAMPMANN 2018) e epigenética de organismos (KANG et al. 2019), utilizando metodologias em que a dCas associa-se a uma sequência codificadora de interes- 
se. Em uma dessas aplicações, ocorre a associação da dCas com a proteína verde fluorescente (Green Fluorescent Protein, GFP). A técnica permite a identificação da regulação gênica espaço-temporal, além de servir como uma ferramenta de diagnose in situ (CHEN et al. 2013). A associação entre GFP e dCas possibilita detectar a fluorescência na região de atividade por meio de microscopia de fluorescência de alta resolução. Entre os recentes avanços desta estratégia, destaca-se a fusão de diferentes proteínas de fluorescência tanto à dCas quanto ao gRNA (JUNQUEIRA et al. 2016). Com a ligação entre dCas ou gRNA e proteínas de fluorescência com diferentes colorações é possível a formação de um painel de diversas cores, reduzindo, dessa forma, a detecção de ligações inespecíficas (JUNQUEIRA et al. 2016).

Com relação ao uso de CRISPR para a regulação da expressão gênica, este objetivo pode ser cumprido via interferência genética ou epigenética. Nesse caso, proteínas reguladoras da transcrição gênica ou indutoras de acetilação de histonas são fusionadas in tandem na região C-terminal na dCas, sendo o gRNA responsável pelo direcionamento ao sítio-alvo (JUNQUEIRA et al. 2016). O gRNA pode ter como alvo regiões a montante do sítio de início da transcrição (Transcription Start Site, TSS), sequências reguladoras (enhancers) e sítios de ligação da RNA polimerase (JUNQUEIRA et al. 2016). A classe da proteína reguladora fusionada à dCas determinará se ocorrerá a indução ou inibição da expressão do gene. Alguns exemplos mais frequentes de proteínas fusionadas à dCas que induzem a expressão gênica são: VP16, VP48, VP64, EDLL, TAD, HAT e acetiltransferase p300 (CHENG et al. 2013, MAEDER et al. 2013, TSANKOV et al. 2015, JUNQUEIRA et al. 2016). O aumento da expressão de um determinado gene pode estar ligado ao recrutamento de fatores de transcrição à região TSS, bem como ao remodelamento da cromatina induzido pela acetilação de histonas, o que torna a região da cromatina disponível para a ligação da maquinaria de transcrição (JUNQUEIRA et al. 2016). Atualmente, ao invés de um, múltiplos ativadores são acoplados à dCas, resultando em um aumento significativo na expressão do gene-alvo comparado com a adição de um único ativador. Um exemplo é o sistema dCas9:VP ou SunTag10x-VP64, onde o primeiro sistema consiste na dCas9 acoplada a seis módulos TAD e dois VP64, e o segundo de 10 anticorpos scFv fusionados a VP64
(TANENBAUM et al. 2014, Ll et al. 2017).

Assim como a ativação gênica, é possível realizar a repressão gênica utilizando exclusivamente dCas9 ou esta molécula fusionada ao repressor KRAB (Kruppel-Associated Box) situado no sítio de ligação de fatores de transcrição ou RNA polimerase (GILBERT et al. 2013). A dCas9-KRAB, além de impedir a ligação da maquinaria de transcrição, é capaz de induzir o estado de heterocromatina na região de ligação, em decorrência da metilação da histona H3 ocasionada pelas proteínas da família HP1 (Heterochromatin Protein 1). Embora simples e robusta, o melhor posicionamento da dCas e o número de gRNA são determinantes para a indução ou inibição da expressão gênica via sistema CRISPR (JUNQUEIRA et al. 2016).

\section{SISTEMAS DE ENTREGA DOS COMPONENTES CRIS- PR/CAS PARA EDIÇÃO DE GENOMAS}

A entrega (delivery) eficiente dos componentes que integram a maquinaria CRISPR/Cas é essencial para uma edição genômica efetiva. Em plantas, os sistemas de entrega passam por um grande desafio: vencer a parede celular, que representa uma barreira física rígida e com múltiplas camadas que dificultam a entrega de biomoléculas intracelularmente (VIEIRA et al. 2020). Outro ponto crucial na edição de genomas de plantas é o seu complexo processo de regeneração (CUNNINGHAM et al. 2018). Os componentes do sistema CRISPR/Cas podem ser entregues às células vegetais a partir de diferentes biomoléculas: (i) vetores de expressão (plasmídeos ou vírus) que codificam a proteína Cas e o gRNA; (ii) mRNA da Cas e gRNA separados; e (iii) proteína Cas conjugada ao gRNA transcrito, formando o chamado complexo ribonucleoproteico (Ribonucleoprotein, RNP) (VIEIRA et al. 2020). A escolha das biomoléculas depende da estratégia de entrega, bem como da possibilidade de classificar a cultivar editada como convencional conforme previsto na Resolução Normativa Número 16 vigente na CTNBio (LINO et al. 2018, VIEIRA et al. 2020). Para que essas biomoléculas entrem nas células vegetais, são utilizados métodos físicos (biobalística), biológicos (Agrobacterium) ou químicos (transformação mediada por polietilenoglicol) (ZHU et al. 2020).

A entrega de vetores plasmidiais para futura expressão da Cas e do gRNA na planta se dá por meio de transformação via Agrobacterium tumefa- 
ciens ou biobalística (CUNNINGHAM et al. 2018). A transformação por $A$. tumefaciens consiste na exportação do T-DNA contendo a maquinaria CRISPR/ Cas (proteína Cas e gRNA), que serão inseridos aleatoriamente no genoma nuclear da planta (CUNNINGHAM et al. 2018). A biobalística consiste no uso de micropartículas de ouro ou tungstênio revestidas com material genético que são aceleradas por pressão de gás hélio e direcionadas ao tecido vegetal, conseguindo, assim, romper a parede celular e ter acesso ao núcleo (VIEIRA et al. 2020). O uso da biolística pode resultar na transformação do genoma nuclear, plastidial ou mitocondrial (CUNNINGHAM et al. 2018).

Embora as técnicas convencionais mencionadas acima sejam robustas, há limitações, tais como: danificação do tecido vegetal, integração do DNA exógeno ao genoma da planta e eficiência limitada a algumas espécies de plantas (RAN et al. 2017). Além disso, os métodos convencionais de entrega do sistema CRISPR/Cas requerem procedimentos de cultura de tecidos (ZHU et al. 2020). Como uma alternativa, vetores virais e não virais (nanopartículas) vêm sendo utilizados como veículos de entrega eficientes, sem a necessidade de regeneração da planta a partir de cultura de tecidos, e permitindo o delivery passivo de biomoléculas na ausência de força externa e sem danos aos tecidos (CUNNINGHAM et al. 2018, LINO et al. 2018).

Alguns vírus são eficientes na edição genômica de plantas devido à capacidade de replicação e movimento nas espécies vegetais (ZHU et al. 2020). Ao longo dos anos, houve uma grande evolução nas pesquisas de vírus como agentes carreadores e envolvidos na edição do genoma de plantas. A princípio, apenas os vírus engenheirados de RNA ou DNA de fita simples (ssRNA ou ssDNA, respectivamente) senso-positivo, como o tobacco rattle virus,TRV (ALI et al. 2015, 2018), tobacco mosaic virus,TMV (CODY et al. 2017), pea early-browning virus (ALI et al. 2018), beet necrotic yellow vein virus (JIANG et al. 2019) e cabbage leaf curl virus (YIN et al. 2015) eram utilizados para expressar fitas de gRNA, requerendo a expressão da Cas em plantas geneticamente modificadas para a efetividade do sistema CRISPR/Cas. Atualmente, é possível a expressão da Cas e gRNA de forma estável em uma única molécula viral, sendo observado até mesmo o efeito transgeracional da edição utilizando vetores virais. Barley yellow striate mosaic virus e sonchus yellow net virus, dois vírus de ssRNA senso-negativo, foram capazes de editar eficientemente plantas de Nicotiana benthamiana, porém, sem efeito transgeracional devido à incapacidade desses vírus penetrarem nos tecidos meristemáticos e reprodutivos da planta (GAO et al. 2019, MA et al. 2020). A indução de mutações nas progênies foi alcançada pela fusão de elementos móveis de RNA ao gRNA em TRV, infiltrado por meio de Agrobacterium (ELLISON et al. 2020).

O uso de nanopartículas, também chamadas de vetores não virais, é outra opção interessante para entrega de componentes CRISPR/Cas devido a diversas características positivas: tamanho reduzido, biocompatibilidade, não citotoxicidade, propriedades físico-químicas ajustáveis e capacidade de entrega e liberação controlada das biomoléculas em compartimentos subcelulares (CUNNINGHAM et al. 2018). Trata-se de moléculas com capacidade de internalização passiva de DNA, RNA e proteínas em plantas (DEMIRER et al. 2019). Recentemente, Zhao e colaboradores (2017) desenvolveram uma nanopartícula magnética de pólen carreadora de DNA, que foi denominada magnetofecção de pólen. A metodologia tem como objetivo usar o polén como agente carreador de moléculas exógenas de DNA e posteriormente usar esse polén para fertilizar o ovário da planta e gerar sementes transgênicas. Diversos grupos destacam a nanotecnologia como uma ferramenta impulsionadora para a criação de ferramentas transformacionais capazes de superar os desafios de entrega dos componentes CRISPR/ Cas e transformação eficiente de plantas. No entanto, muito ainda precisa ser aprimorado no desenvolvimento de nanotubos de carbono, nanopartículas poliméricas, fosfato de cálcio, sílica e novos nanocarreadores.

\section{VANTAGENS E DESVANTAGENS DO USO DO SISTE- MA CRISPR/CAS NA FITOPATOLOGIA}

A utilização da tecnologia CRISPR/Cas, além de fácil aplicação e custo baixo, pode acelerar o desenvolvimento de plantas resistentes a patógenos e/ou alcançar resultados que seriam impossíveis usando as técnicas convencionais de transformação de plantas. A descoberta dessa tecnologia alterou os processos de edição genômica e superou as deficiências dos métodos de transformação, como a inexistência de genes marcadores, incorporação de 
vetores e a capacidade de modificar o genoma da planta de forma sítio direcionada. Dessa forma, esses avanços permitiram a geração de plantas resistentes a fitopatógenos sem a inserção de genes exógenos no genoma (CHEN et al. 2019). No entanto, a técnica tem como limitação a necessidade de uma região PAM próximo ao alvo e, algumas vezes, uma baixa especificidade da enzima Cas e gRNA para reduzir as chances de off-target. Dessa forma as possibilidades de edição genômica serão cada vez mais amplas e eficientes.

\section{EDIÇÃO GENÔMICA PARA O CONTROLE DE DOEN- ÇAS DE PLANTAS}

Os fitopatógenos, de forma geral, apresentam elevada variabilidade fenotípica e/ou genotípica capazes de suplantar a resistência de plantas (HEITMAN et al. 2017). A edição de genes de suscetibilidade da hospedeira tem sido uma estratégia rápida e eficiente na reversão deste cenário. Além disso, o sistema CRISPR/Cas é especialmente útil para culturas com reduzida fonte de resistência, poliploides e com longos ciclos de vida. Os trabalhos de edição genética de plantas pelo sistema CRISPR/Cas visando ao controle de fitopatógenos têm sido realizados principalmente por meio do mecanismo de reparo NHEJ, focando no nocaute de genes de suscetibilidade com diferentes estratégias de entrega das biomoléculas. Alguns exemplos do sistema CRISPR/Cas aplicado à edição genômica para resistência a fitopatógenos serão mencionados a seguir. Um resumo com os principais trabalhos utilizando CRISPR para controle de fitopatógenos foi incluído na Tabela 1.

\section{CRISPR/CAS NO CONTROLE DE FUNGOS FITOPATO- GÊNICOS}

As doenças causadas por fungos constituem a maioria das enfermidades de plantas, reduzindo significativamente o rendimento e a qualidade das culturas (MUÑOZ et al. 2019, YIN \& QIU 2019). Há alguns exemplos de plantas submetidas a edições genômicas usando o sistema CRISPR/Cas para induzir resistência a fungos. O cacaueiroa (Theobroma cacao) é a principal matéria prima para a produção de chocolate, sendo a base econômica de muitos países em desenvolvimento (FISTER et al. 2018). No entanto, diversas doenças acometem a cultura, como a podridão-parda causada por Phytophthora tropicalis (FISTER et al. 2018). Com intuito de obter plantas de cacau resistentes a este fungo, o gene $T c$ NPR3 de T. cacao, homólogo ao gene NPR3 de Arabidopsis, repressor de resposta de defesa da planta, foi alvo de edição via CRISPR/Cas9 por meio da expressão transiente da Cas9 e transcritos de gRNA. Como resultado, o nocaute do gene TCNPR3 aumentou a resistência do cacaueiro contra $P$. tropicalis (FISTER et al. 2018).

O algodoeiro (Gossypium hirsutum) possui características que dificultam as abordagens clássicas de melhoramento, por ser uma espécie alotetraploide, o que também torna desafiadora a manipulação gênica da espécie (ZHANG et al. 2018b). As proteínas 14-3-3 são uma família de moléculas que se ligam a sinalizadores dos tipos quinases, fosfatases e receptores transmembranares no algodoeiro (OBSIL et al. 2001). Além disso, estas proteínas conseguem interferir na resposta ao estresse biótico (NAKASHITA et al. 2003, VRIET et al. 2012, WANG et al. 2012), a exemplo do parasitismo por Verticillium dahliae (GAO et al. 2013). Assim, o nocaute do gene Gh14-3-3 via sistema CRISPR/Cas por transformação mediada por Agrobacterium levou à maior resistência contra V. dahliae (ZHANG et al. 2018b).

Similar ao fungo $V$. dahliae, Magnaporthe oryzae, agente etiológico da brusone, causa perdas significativas na cultura do arroz (Oryza sativa). Atualmente, a indução de resistência é a abordagem mais econômica e eficaz para o controle deste fitopatógeno (LIU et al. 2014). Estudos demonstraram que o gene OSERF922, fator de resposta ao etileno (ERF), é induzido por patógenos virulentos e seu nocaute resultou em resistência contra $M$. oryzae (LIU et al. 2012). Além disso, esse gene integra a rede de sinalização de estresses bióticos e abióticos, sofrendo influência da expressão de acordo com o nível de ácido abscísico (LIU et al. 2012). Sabendo da importância do gene na interação planta-patógeno, Wang e colaboradores (2016) nocautearam o gene OsERF922 em arroz. Na mesma cultura, sistema similar foi aplicado para nocautear o gene OSSEC3A, responsável pelo aumento no conteúdo de ácido salicílico (SA) e indução de respostas de defesa da planta (MA et al. 2018). Como resultado, em ambos os estudos houve redução no número de lesões nos estádios de plântulas e perfilhamento.

Outra doença capaz de causar danos em diversas culturas é o oídio. A edição genômica usando o sistema CRISPR/Cas vem sendo o foco para o seu 
controle. O alelo mildew-resistance locus O (MLO), que codifica uma proteína associada à membrana com sete domínios transmembranares, confere suscetibilidade ao oídio (ACEVEDO-GARCIA et al. 2014). $O$ nocaute deste gene foi realizado em diferentes culturas na busca da resistência à doença. Em tomateiro (Solanum lycopersicum), o gene SiMLO1 foi editado e a perda de função foi mediada por Agrobacterium (NEKRASOV et al. 2017). Após a transformação e observação de indels no gene-alvo da geração T0 e suas progênies, foi possível identificar cinco indivíduos não-transgênicos e com resistência total ao patógeno (NEKRASOV et al. 2017). A mesma família de gene foi mutada em videira e trigo. Em videira (Vitis sp.), a entrega das biomoléculas ocorreu via protoplastos mediada por polietilenoglicol usando o complexo RNP para nocautear o gene MLO7 que confere resistência ao oídio da videira (Erysiphe necator) (MALNOY et al. 2016). Em trigo (Triticum aestivum), uma espécie de difícil modificação por sua natureza poliploide, a entrega das biomoléculas foi realizada por meio de biobalística com alvo na perda da atividade dos genes TaMLO-A1, TaMLO-B1 e TaMLO-D1, também visando conferir resistência ao oídio (Blumeria graminis f. sp. tritici) (WANG et al. 2014). Essas estratégias mostraram-se eficazes para a mutagênese direcionada em protoplastos de videira e trigo, sendo as plantas geradas não consideradas OGM (MALNOY et al. 2016). O nocaute do gene TaEDR1, envolvido na cascata de MAP quinase que regula negativamente as respostas de defesa induzidas por SA, também apresentou boa resposta de resistência ao oídio quando nocauteado via sistema CRISPR/Cas (ZHANG et al. 2017).

\section{CRISPR/CAS NO CONTROLE DE BACTÉRIAS FITOPA- TOGÊNICAS}

Para doenças bacterianas, que, em geral são de difícil controle (YIN \& QIU 2019), a maioria dos trabalhos envolve edição genômica de plantas usando o sistema CRISPR/Cas por meio de nocaute dos genes de interesse via NHEJ, mediado por transformação via Agrobacterium (DE TOLEDO THOMAZELLA et al. 2016, JIA et al. 2017, OLIVA et al. 2019, ORTIGOSA et al. 2019).

O melhoramento tradicional de citros enfrenta desafios intrínsecos da cultura que limitam os avanços das pesquisas, como a poliploidia, poliembrionia, ciclos de cruzamento longos e prolongados
(DAVEY et al. 2005). Assim, para o desenvolvimento de novas variedades, a edição genômica tem impulsionado o andamento e expansão dos estudos visando a obtenção de variedades resistentes à fitobacterioses. O cancro cítrico, que tem como agente causal a bactéria Xanthomonas citri subsp. citri, é uma das principais doenças em citros. Durante a infecção, fatores da bactéria induzem a ativação do gene de suscetibilidade CSLOB1 (HU et al. 2014, JIA et al. 2017). Com o nocaute e confirmação da mutação na região codificante desse gene, foram obtidas plantas resistentes ao cancro cítrico, além de não terem sido observados efeitos indesejados como mudanças fenotípicas e mutações off-targets nas plantas transformadas (JIA et al. 2017). Contudo, ainda é necessário gerar variedades de citros sem a incorporação do material genético da Cas9 e gRNA nas plantas, visando facilitar a sua desregulamentação (JIA et al. 2017).

Alguns genes de suscetibilidade envolvidos no transporte de sacarose da família SWEET também foram identificados em arroz. Mutações via CRISPR/Cas9 nas regiões promotoras dos genes OsSWEET11, OsSWEET13 e OSSWEET14 de O. sativa resultaram em uma resistência robusta e de amplo espectro (OLIVA et al. 2019). Os genes OsSWEET13 (ZHOU et al. 2015) e OsSWEET11 (KIM et al. 2019) também foram editados separadamente pelos componentes do sistema CRISPR/Cas9, e ambos os trabalhos demonstraram efeito de resistência à $X$. oryzae pv. oryzae.

O gene SiDMR6, associado à homeostase de SA, interfere na entrada de patógenos, como a bactéria Pseudomonas syringae, induzindo o fechamento estomático e restringindo a colonização do tecido da hospedeira (DE TOLEDO THOMAZELLA et al. 2016, GIMENEZ-IBANEZ et al. 2017). O nocaute deste gene foi possível via CRISPR/Cas9 e os resultados demonstraram resistência do tomateiro a $P$. syringae, P. capsici e Xanthomonas spp. (DE TOLEDO THOMAZELLA et al. 2016). Influenciada por SA, $P$. syringae desenvolveu um mecanismo capaz de permitir a abertura estomática produzindo coronatina (COR), que inibe as defesas dependentes de SA (FONSECA et al. 2009). A COR é reconhecida pelos cofatores COI1 e JAZ, sendo essencial para o funcionamento e expressão deste gene. O nocaute do gene $J A Z$ por CRISPR/Cas9 resultou em resposta de resistência a $P$. syringae devido à incapacidade de 
indução da abertura estomática (ORTIGOSA et al. 2019).

\section{CRISPR/CAS NO CONTROLE DE VÍRUS FITOPATOGÊ- NICOS}

O sistema CRISPR/Cas pode ser utilizado para controle de viroses em plantas por meio da indução de clivagem direta do DNA ou RNA virais e por nocaute do gene de suscetibilidade da planta hospedeira (ZHU et al. 2020). Usando a estratégia de clivagem de DNA viral, resultados interessantes quanto ao nível de imunidade das plantas foram obtidos, principalmente contra geminivírus e caulimovírus (JI et al. 2018, LIU et al. 2018). Baltes et al. (2015) e Ji et al. (2015) desenvolveram plantas transgênicas de Arabidopsis e $N$. benthamiana expressando constitutivamente a nuclease Cas9 e gRNAs com homologia aos genes de replicação $(R E P)$, capa proteica $(C P)$ e região intergênica $(I R)$ de geminivírus. A inativação desses genes foi capaz de reduzir ou eliminar os sintomas causados por bean yellow dwarf virus e beet severe curly top virus. O nocaute de CP e REP parece ser uma estratégia eficaz para controle de geminivírus, uma vez que esses genes também foram utilizados para obtenção de plantas de tabaco e tomate com alto nível de resistência a tomato yellow leaf curl virus (TYLCV). O nocaute dos genes resultou em baixo acúmulo do material genético de TYLCV nas plantas transgênicas, resposta que perdurou até as gerações subsequentes (TASHKANDI et al. 2018). Em tabaco, também se detectou bons resultados com o nocaute da REP para conferir resistência a cotton leaf curl multan virus (YIN et al. 2019). De acordo com Yin e colaboradores (2019), a expressão de Cas9 e gRNAs duplos, que editam simultaneamente várias regiões dos genomas de vírus de DNA, é uma técnica eficaz para a obtenção de plantas com resistência completa a doenças induzidas por vírus de DNA.

Um exemplo interessante da aplicação do sistema CRISPR/Cas na família Caulimoviridae é o controle do banana streak virus (BSV), um vírus de dsDNA capaz de se integrar ao genoma da bananeira (Musa spp.). O sistema CRISPR/Cas9 foi utilizado visando inativar as sequências de eBSV (BSV endógeno) no genoma da bananeira. A estratégia induziu a formação de indels nas ORFs 1 e 2 do vírus (TRIPATHI et al. 2019). No entanto, vale mencionar que, embora mutações direcionadas a DNAs virais usando o sistema CRISPR/Cas seja uma estratégia aparentemente bem estabelecida, resultados controversos foram obtidos, indicando baixos níveis ou nenhuma resistência com o uso dessa tecnologia para o controle de alguns vírus de DNA em plantas (MEHTA et al. 2019).

Com relação ao controle de vírus com genomas constituídos de RNA, diferentes nucleases Cas capazes de clivar fitas de RNA têm sido utilizadas, uma vez que o tradicional sistema CRISPR/Cas9 é restrito à clivagem de moléculas de dsDNA. Algumas destas enzimas são: Cas13a, Cas13b, Cas13d e Cas9 de Francisella novicida (FnCas9) (ZHANG et al. 2018, MAHAS et al. 2019). Recentemente, a FnCas9 foi utilizada em tabaco e Arabidopsis para o controle de cucumber mosaic virus e TMV, vírus com genomas de ssRNA (ZHANG et al. 2018). Para isso, plantas transgênicas foram desenvolvidas a partir da transformação mediada por Agrobacterium com o método de imersão floral. Como resultado, o acúmulo viral foi reduzido e os sintomas atenuados (ZHANG et al. 2018). Experimento similar foi realizado utilizando a nuclease Cas13a de Leptotrichia shahii levando à resistência das plantas de tabaco contra o turnip mosaic virus (TuMV) (AMAN et al. 2018).

Embora a estratégia de utilização do sistema CRISPR/Cas para clivagem e desativação direta dos genomas virais seja promissora, a principal forma de controle de viroses em plantas ainda é a mutação de genes de suscetibilidade da hospedeira. As edições de plantas para resistência a viroses, assim como para os outros fitopatógenos, ocorrem predominantemente via entrega das biomoléculas mediada por Agrobacterium. Como exemplo, o gene elF4E, fator de iniciação da tradução nas células vegetais e necessário para a tradução de proteínas virais, é um dos principais alvos no controle de viroses em plantas (SANFAÇON 2015). O nocaute desse gene por CRISPR/Cas9 resultou em resistência a TuMV em Arabidopsis (PYOTT et al. 2016).

A mandioca (Manihot esculenta) é afetada por doenças de etiologia viral, como o cassava brown streak virus e ugandan cassava brown streak virus, ambos da família Potyviridae (GOMEZ et al. 2019). Para o processo de replicação dos membros desta família, ocorre interação entre a proteína elF4E da hospedeira e a proteína viral VPg (Viral Protein Genome-Linked). Os genes nCBP-1 e nCBP-2, isoformas de elF4E, foram alvos de edição media- 
da por CRISPR/Cas9 em mandioca (GOMEZ et al. 2017, 2019). Mutações nesses genes resultaram no retardo do aparecimento de sintomas aéreos, bem como na menor incidência de necrose na raiz (GOMEZ et al. 2017, 2019). O nocaute de elF4E também foi realizado em plantas de pepino (Cucumis sativus) para indução de resistência contra cucumber vein yellowing virus, zucchini yellow mosaic virus e papaya ringspot virus-W (CHANDRASEKARAN et al. 2016).

Outro genealvo que foi mutado na tentativa de controlar viroses foi o gene coilin, que codifica a proteína coilina (MAKHOTENKO et al. 2019). A proteína coilina pode participar do metabolismo de RNA, montagem, modificação e transporte de ribonucleoproteínas, podendo também afetar interações planta-vírus (MAKHOTENKO et al. 2019). Para a edição do gene coilin, um complexo consistindo de Cas9 e gRNA foi imobilizado em micropartículas de ouro ou quitosana e entregue às células do meristema apical da batata (Solanum tuberosum) por biobalística ou métodos de infiltração a vácuo, respectivamente. A introdução da maquinaria CRISPR/ Cas9 possibilitou a edição do gene-alvo, aumentando consideravelmente a resistência das plantas contra a infecção por potato virus Y (MAKHOTENKO et al. 2019).

\section{CRISPR/CAS NO CONTROLE DE NEMATOIDES FITO- PATOGÊNICOS}

O uso da tecnologia CRISPR/Cas no controle de fitonematoides depende da identificação e edição de genes de suscetibilidade da planta hospedeira ou genes relacionados ao parasitismo do nematoide (ALI et al. 2019). Diversos estudos utilizando a ferramenta CRISPR/Cas foram realizados em Caenorhabditis elegans (CHO et al. 2013, DICKINSON et al. 2013, FRIEDLAND et al. 2013, KATIC \& GROBHANS 2013, TZUR et al. 2013, WAAIJERS et al. 2013, DICKINSON \& GOLDSTEIN 2016, PAIX et al. 2017) e C. briggsae (CULP et al. 2020), na tentativa de caracterizar genes envolvidos em processos fisiológicos dos nematoides e entender aspectos das interações nematoide-planta. Kang (2016) estudou o potencial da ferramenta para identificar genes de soja com papel na resistência ao nematoide de cisto Heterodera glycines. Entre os resultados, o autor caracterizou a função do gene Rhg4, responsável por codificar uma serina hidroximetiltransferase relacionada com a resistência à $H$. glycines. Pesquisas envolvendo a tecnologia CRISPR/Cas para controle de nematoides em plantas ainda são escassas. O avanço nos estudos com estes fitopatógenos é estritamente necessário para a obtenção de cultivares resistentes via CRISPR/Cas (ALl et al. 2019).

\section{PERSPECTIVAS FUTURAS}

A edição genômica utilizando o sistema CRIS$\mathrm{PR} /$ Cas vem alavancando as pesquisas na área de melhoramento de plantas e superando as limitações dos métodos convencionais, como o tempo gasto com cruzamentos e seleção de genes promissores (YIN \& QIU 2019). É incontestável a capacidade de edição via CRISPR/Cas de forma precisa, o que possibilitou a criação de centenas de cultivares/variedades com maior resistência a fitopatógenos. Até o momento, na maioria das pesquisas na área da $\mathrm{Fi}$ topatologia utilizou-se essa tecnologia para induzir mutações do tipo indel. Porém, uma série de variantes e enzimas Cas engenheiradas estão disponíveis e possibilitam manipulações genéticas diversificadas. Além disso, houve avanços com relação à forma de entrega das biomoléculas do sistema CRISPR/ Cas por meio de partículas virais e nanocarreadores para facilitar a edição genômica e reduzir off-targets. No entanto, novos materiais são desejados para viabilizar a entrega mais eficiente e possibilitar edições nucleares, mitocondriais e de cloroplastos de forma passiva.

O nocaute de genes de suscetibilidade das hospedeiras é a principal estratégia para induzir resistência a fitopatógenos. Portanto, são necessários estudos adicionais na área de genômica funcional para descoberta de novos genes de suscetibilidade em culturas de importância econômica (YIN \& QIU 2019). Outro ponto essencial que vem sendo discutido são as normas de regulamentação da tecnologia CRISPR/Cas. Diversos países, incluindo o Brasil, podem classificar como não GM, a partir de suas normativas específicas, plantas editadas obtidas por abordagem que resulte na ausência de DNA recombinante em seu produto final (VIEIRA et al. 2020). No Brasil, segundo a Resolução Normativa no 16 da CTNBio, é considerado organismo não GM: (i) material genético com ausência de DNA/RNA recombinante; (ii) organismos contendo elementos genéticos adquiridos por meio de cruzamentos convencionais ou outra tecnologia; e (iii) mutações ob- 
Tabela 1. Resumo com os principais trabalhos utilizando CRISPR para controle de fipatógenos em diferentes culturas.

\begin{tabular}{|c|c|c|c|}
\hline \multicolumn{4}{|c|}{ Fungos } \\
\hline Cultura & Gene(s) alvo(s) & Fitopatógeno alvo & Referência \\
\hline Cacaueiro & TcNPR3 & Phytophthora tropicalis & FISTER et al. (2018) \\
\hline Algodoeiro & Gh14-3-3 & Verticillium dahliae & ZHANG et al. (2018b) \\
\hline Arroz & OsERF922 & Magnaporthe oryzae & Wang et al. (2016) \\
\hline Arroz & OSSEC3A & Magnaporthe oryzae & MA et al. (2018) \\
\hline Tomateiro & SiMLO1 & Oidium neolycopersici & NEKRASOV et al. (2017) \\
\hline Videira & MLO7 & Erysiphe necator & MALNOY et al. (2016) \\
\hline Trigo & $\begin{array}{l}\text { TaMLO-A1, TaMLO- } \\
\text {-B1 e TaMLO-D1 }\end{array}$ & Blumeria graminis $f . \mathrm{sp}$. tritici & WANG et al. (2014) \\
\hline Trigo & TaEDR1 & Blumeria graminis $f$. sp. tritici & ZHANG et al. (2017) \\
\hline \multicolumn{4}{|c|}{ Bacterioses } \\
\hline Cultura & Gene(s) alvo(s) & Fitopatógeno alvo & Referência \\
\hline Citros & CsLOB1 & Xanthomonas citri_subsp. citri & JIA et al. (2017) \\
\hline Arroz & $\begin{array}{l}\text { OsSWEET11, Os- } \\
\text { SWEET13 e OsS- } \\
\text { WEET14 }\end{array}$ & Xanthomonas oryzae & OLIVA et al. (2019) \\
\hline Arroz & OsSWEET13 & Xanthomonas oryzae & ZHOU et al. (2015) \\
\hline Arroz & OsSWEET11 & Xanthomonas oryzae & KIM et al. (2019) \\
\hline Tomateiro & SiDMR6 & $\begin{array}{l}\text { Pseudomonas syringae e Xanthomonas } \\
\text { spp. }\end{array}$ & DE TOLEDO THOMAZELLA et al. (2016) \\
\hline Tomateiro & $J A Z$ & Pseudomonas syringae & ORTIGOSA et al. (2019) \\
\hline \multicolumn{4}{|c|}{ Viroses } \\
\hline Cultura & Gene(s) alvo(s) & Fitopatógeno alvo & Referência \\
\hline $\begin{array}{l}\text { Arabidopsis e } N \\
\text { benthamiana }\end{array}$ & $R E P, C P$ e $I R$ & $\begin{array}{l}\text { Bean yellow dwarf virus e beet severe } \\
\text { curly top virus }\end{array}$ & BALTES et al. (2015) e Jl et al. (2015) \\
\hline Tabaco e tomate & $C P$ e $R E P$ & Tomato yellow leaf curl virus & TASHKANDI et al. (2018) \\
\hline Tabaco & $R E P$ & Cotton leaf curl multan virus & YIN et al. (2019) \\
\hline Banana & eBSV & Banana streak virus & TRIPATHI et al. (2019) \\
\hline Arabidopsis & elF4E & Turnip mosaic virus & PYOTT et al. (2016) \\
\hline Mandioca & $n C B P-1$ e $n C B P-2$ & $\begin{array}{l}\text { Cassava brown streak virus e ugandan } \\
\text { cassava brown streak virus }\end{array}$ & GOMEZ et al. $(2017,2019)$ \\
\hline Pepino & elF4E & $\begin{array}{l}\text { Cucumber vein yellowing virus, zucchini } \\
\text { yellow mosaic virus e papaya ringspot } \\
\text { virus W }\end{array}$ & CHANDRASEKARAN et al. (2016) \\
\hline Batata & Coilin & Potato virus $Y$ & MAKHOTENKO et al. (2019) \\
\hline
\end{tabular}

tidas de forma semelhante a agentes mutagênicos ou ocorridas naturalmente (MOLINARI et al. 2020). Essa classificação pode democratizar ainda mais o desenvolvimento científico sobre CRISPR/Cas em todo o mundo e, com isso, essa ferramenta continuará contribuindo, de forma precisa e rápida, para os avanços tecnológicos no controle efetivo e duradouro de fitopatógenos.

\section{REFERÊNCIAS BIBLIOGRÁFICAS}

ACEVEDO-GARCIA J, KUSCH S, PANSTRUGA R (2014). Magical mystery tour: MLO proteins in plant immunity and beyond. New Phytologist 204 (2): 273-281. (https://doi.org/10.1111/ nph.12889).

ANDOLFO G, IOVIENO P, FRUSCIANTE L, ERCOLANO MR. (2016). Genome-editing technologies for 
enhancing plant disease resistance. Frontiers in Plant Science 7: 1813. (https://doi.org/10.3389/ fpls.2016.01813).

ALI MA, SHAHZADI M, ZAHOOR A, DABABAT AA, TOKTAY H, BAKHSH A, ..., LI H (2019). Resistance to cereal cyst nematodes in wheat and barley: an emphasis on classical and modern approaches. International Journal of Molecular Sciences 20(2): 432. (https://doi.org/10.3390/ijms20020432).

ALI Z, ABULFARAJ A, IDRIS A, ALI S, TASHKANDI M, MAHFOUZ MM (2015). CRISPR/Cas9-mediated viral interference in plants. Genome Biology 16 (1): 238. (https://doi.org/10.1186/s13059015-0799-6).

ALI Z, EID A, ALI S, MAHFOUZ MM (2018). Pea early-browning virus-mediated genome editing via the CRISPR/Cas9 system in Nicotiana benthamiana and Arabidopsis. Virus Research 244: 333-337. (ttps://doi.org/10.1016/j.virusres.2017.10.009).

AMAN R, ALI Z, BUTT H, MAHAS A, ALJEDAANI F, KHAN MZ, DING S, MAHFOUZ M (2018). RNA virus interference via CRISPR/Cas13a system in plants. Genome Biology 19(1): 1-9. (https://doi. org/10.1186/s13059-017-1381-1).

ANANTHARAMAN V, IYER LM, ARAVIND L (2010). Presence of a classical RRM-fold palm domain in Thg1-type 3'-5'nucleic acid polymerases and the origin of the GGDEF and CRISPR polymerase domains. Biology Direct 5(1): 43. (https://doi. org/10.1186/1745-6150-5-43).

ANDRES SN, VERGNES A, RISTIC D, WYMAN C, MODESTI M, JUNOP M (2012). A human XRCC4XLF complex bridges DNA. Nucleic Acids Research 40(4): 1868-1878. (https://doi.org/10.1093/nar/ gks022).

ANZALONE AV, KOBLAN LW, LIU DR (2020). Genome editing with CRISPR-Cas nucleases, base editors, transposases and prime editors. Nature Biotechnology 38(7): 824-844. (https://doi. org/10.1038/s41587-020-0561-9).

ANZALONE AV, RANDOLPH PB, DAVIS JR, SOUSA AA, KOBLAN LW, LEVY JM, ..., LIU DR (2019). Search-and-replace genome editing without double-strand breaks or donor DNA. Nature 576(7785): 149-157. (https://doi.org/10.1038/ s41586-019-1711-4).

BALTES NJ, HUMMEL AW, KONECNA E, CEGAN $R, B R U N S$ AN, BISARO DM, VOYTAS DF (2015).
Conferring resistance to geminiviruses with the CRISPR-Cas prokaryotic immune system. Nature Plants 28;1(10): 1-4. (https://doi.org/10.1038/ nplants.2015.145).

BARRANGOU R, FREMAUX C, DEVEAU $\mathrm{H}$, RICHARDS M, BOYAVAL P, MOINEAU S, ...., HORVATH $P$ (2007). CRISPR provides acquired resistance against viruses in prokaryotes. Science 315(5819): 1709-1712. (10.1126/science.1138140).

BHAYA D, DAVISON M, BARRANGOU R (2011) CRISPR-Cas Systems in Bacteria and Archaea: Versatile Small RNAs for Adaptive Defense and Regulation. Annual Review of Genetics 45:273$97 . \quad$ (https://doi.org/10.1146/annurev-genet-110410-132430).

BIBIKOVA M, GOLIC M, GOLIC KG, CARROLL D (2002). Targeted chromosomal cleavage and mutagenesis in Drosophila using zinc-finger nucleases. Genetics 161(3): 1169-1175.

BOLOTIN A, QUINQUIS B, SOROKIN A, EHRLICH SD (2005). Clustered regularly interspaced short palindrome repeats (CRISPRs) have spacers of extrachromosomal origin. Microbiology 151(8): 25512561. (https://doi.org/10.1099/mic.0.28048-0).

BORTESI L, FISCHER R (2015). The CRISPR/Cas9 system for plant genome editing and beyond. Biotechnology Advances 33(1): 41-52. (https://doi. org/10.1016/j.biotechadv.2014.12.006).

BUTT H, EID A, ALI Z, ATIA MA, MOKHTAR MM, HASSAN N, ..., MAHFOUZ MM (2017). Efficient CRISPR/Cas9-mediated genome editing using a chimeric single-guide RNA molecule. Frontiers in Plant Science 8: 1441. (https://doi.org/10.3389/ fpls.2017.01441).

CERMÁK T, BALTES NJ, CEGAN R, ZHANG Y, VOYTAS DF (2015). High-frequency, precise modification of the tomato genome. Genome Biology 16(1): 232. (https://doi.org/10.1186/s13059-0150796-9).

CHANDRASEKARAN J, BRUMIN M, WOLF D, LEIBMAN D, KLAP C, PEARLSMAN M, ..., GALON A (2016). Development of broad virus resistance in non-transgenic cucumber using CRISPR/Cas9 technology. Molecular Plant Pathology 17(7): 1140-1153. (https://doi.org/10.1111/ mpp.12375).

CHEN B, GILBERT LA, CIMINI BA, SCHNITZBAUER J, ZHANG W, LI GW, ...., HUANG B (2013). Dynamic imaging of genomic loci in living human 
cells by an optimized CRISPR/Cas system. Cell 155(7): 1479-1491. (https://doi.org/10.1016/j. cell.2013.12.001).

CHEN K, WANG Y, ZHANG R, ZHANG H, GAO C (2019). CRISPR/Cas genome editing and precision plant breeding in agriculture. Annual Review of Plant Biology 70: 667-697. (https://doi. org/10.1146/annurev-arplant-050718-100049).

CHENG AW, WANG $H$, YANG $H, S H I L$, KATZ $Y$, THEUNISSEN TW, ..., JAENISCH R (2013). Multiplexed activation of endogenous genes by CRISPR-on, an RNA-guided transcriptional activator system. Cell Research 23(10): 1163-1171. (https://doi.org/10.1038/cr.2013.122).

CHO SW, LEE J, CARROLL D, KIM JS, LEE J (2013). Heritable gene knockout in Caenorhabditis elegans by direct injection of Cas9-sgRNA ribonucleoproteins. Genetics 195(3): 1177-1180. (https:// doi.org/10.1534/genetics.113.155853).

CHRISTIAN M, CERMAK T, DOYLE EL, SCHMIDT C, ZHANG F, HUMMEL A, ..., VOYTAS DF (2010). Targeting DNA double-strand breaks with TAL effector nucleases. Genetics 186(2): 757-761. (https://doi.org/10.1534/genetics.110.120717).

CHYOU TY, BROWN CM (2019). Prediction and diversity of tracrRNAs from type II CRISPR-Cas systems. RNA Biology 16(4): 423-434. (https://doi.or $\mathrm{g} / 10.1080 / 15476286.2018 .1498281)$.

CODY WB, SCHOLTHOF HB, MIRKOV TE (2017). Multiplexed gene editing and protein overexpression using a tobacco mosaic virus viral vector. Plant Physiology 175(1): 23-35. (https://doi. org/10.1104/pp.17.00411).

CONG L, RAN FA, COX D, LIN S, BARRETTO R, HABIB N, ..., ZHANG F (2013). Multiplex genome engineering using CRISPR/Cas systems. Science 339(6121): 819-823. (10.1126/science.1231143). CORREDOR-MORENO P, SAUNDERS DG (2020). Expecting the unexpected: factors influencing the emergence of fungal and oomycete plant pathogens. New Phytologist 225(1): 118-125. (https:// doi.org/10.1111/nph.16007).

CUI Y, DONG H, MA Y, ZHANG D (2019). Strategies for applying nonhomologous end joining-mediated genome editing in Prokaryotes. ACS Synthetic Biology 8(10): 2194-2202. (https://doi. org/10.1021/acssynbio.9b00179).

CULP E, RICHMAN C, SHARANYA D, JHAVERI N, VAN DEN BERG W, GUPTA BP (2020). Genome editing in the nematode Caenorhabditis briggsae using the CRISPR/Cas9 system. Biology Methods and Protocols 5(1): bpaa003. (https://doi. org/10.1093/biomethods/bpaa003).

CUNNINGHAM FJ, GOH NS, DEMIRER GS, MATOS JL, LANDRY MP (2018). Nanoparticle-mediated delivery towards advancing plant genetic engineering. Trends in Biotechnology 36(9): 882-897. (https://doi.org/10.1016/j.tibtech.2018.03.009).

DAVEY MR, ANTHONY P, POWER JB, LOWE KC (2005). Plant protoplasts: status and biotechnological perspectives. Biotechnology Advances 23(2): 131-171. (https://doi.org/10.1016/j.biotechadv.2004.09.008).

DAVIS AJ, CHEN BP, CHEN DJ (2014). DNA-PK: a dynamic enzyme in a versatile DSB repair pathway. DNA Repair (Amst) 17: 21-29. (https://doi. org/10.1016/j.dnarep.2014.02.020).

DE TOLEDO THOMAZELLA DP, BRAIL Q, DAHLBECK D, STASKAWICZ B (2016). CRISPR-Cas9 mediated mutagenesis of a DMR6 ortholog in tomato confers broad-spectrum disease resistance. BioRxiv 064824. (https://doi.org/10.1101/064824).

DELTCHEVA E, CHYLINSKI K, SHARMA CM, GONZALES K, CHAO Y, PIRZADA ZA, ..., CHARPENTIER E (2011). CRISPR RNA maturation by trans-encoded small RNA and host factor RNase III. Nature 471(7340): 602-607. (https://doi.org/10.1038/ nature09886).

DEMIRER GS, ZHANG H, MATOS JL, GOH NS, CUNNINGHAM FJ, SUNG Y, ..., STASKAWICZ B (2019). High aspect ratio nanomaterials enable delivery of functional genetic material without DNA integration in mature plants. Nature Nanotechnology 14(5): 456-464. (https://doi.org/10.1038/s41565019-0382-5).

DEVEAU $H$, BARRANGOU R, GARNEAU JE, LABONTÉ J, FREMAUX C, BOYAVAL P, ..., MOINEAU $S$ (2008). Phage response to CRISPR-encoded resistance in Streptococcus thermophilus. Journal of Bacteriology 190(4): 1390-1400. (10.1128/ JB.01412-07).

DEVEAU H, GARNEAU JE, MOINEAU S (2010). CRISPR/Cas system and its role in phage-bacteria interactions. Annual Review of Microbiology 64: 475-493. (https://doi.org/10.1146/annurev. micro.112408.134123).

DICKINSON DJ, GOLDSTEIN B (2016). CRISPR-based methods for Caenorhabditis elegans genome en- 
gineering. Genetics 202(3): 885-901. (https://doi. org/10.1534/genetics.115.182162).

DICKINSON DJ, WARD JD, REINER DJ, GOLDSTEIN $B$ (2013). Engineering the Caenorhabditis elegans genome using Cas9-triggered homologous recombination. Nature Methods 10(10): 10281034. (https://doi.org/10.1038/nmeth.2641).

DREISSIG S, SCHIML S, SCHINDELE P, WEISS O, RUTTEN T, SCHUBERT V, ..., HOUBEN A (2017). Live cell CRISPR imaging in plants reveals dynamic telomere movements. The Plant Journal 91(4): 565-573. (https://doi.org/10.1111/tpj.13601).

EAST-SELETSKY A, O'CONNELL MR, KNIGHT SC, BURSTEIN D, CATE JH, TJIAN R, DOUDNA JA (2016). Two distinct RNase activities of CRISPR-C2c2 enable guide-RNA processing and RNA detection. Nature 538(7624): 270-273. (https:// doi.org/10.1038/nature19802).

ELLISONEE, NAGALAKSHMIU, GAMO ME, HUANG PJ, DINESH-KUMAR S, VOYTAS DF (2020). Multiplexed heritable gene editing using RNA viruses and mobile single guide RNAs. Nature Plants 1-5. (https://doi.org/10.1038/s41477-020-0670-y).

FAURE G, SHMAKOV SA, MAKAROVA KS, WOLF YI, CRAWLEY AB, BARRANGOU R, KOONIN EV (2019). Comparative genomics and evolution of trans-activating RNAs in Class 2 CRISPR-Cas systems. RNA Biology 16(4), 435-448. (https://doi.or g/10.1080/15476286.2018.1493331).

FENG Z, ZHANG B, DING W, LIU X, YANG DL, WEI $P$, ..., ZHU JK (2013). Efficient genome editing in plants using a CRISPR/Cas system. Cell research 23(10): 1229-1232. (https://doi.org/10.1038/ cr.2013.114).

FISTER AS, LANDHERR L, MAXIMOVA SN, GUILTINAN MJ (2018). Transient expression of CRISPR/ Cas9 machinery targeting TcNPR3 enhances defense response in Theobroma cacao. Frontiers in Plant Science 9: 268. (https://doi.org/10.3389/ fpls.2018.00268).

FONFARA L, RICHTER H, BRATOVIČ M, LE RHUN A, CHARPENTIER E (2016). The CRISPR-associated DNA-cleaving enzyme Cpf1 also processes precursor CRISPR RNA. Nature 532(7600): 517-521. (https://doi.org/10.1038/nature17945).

FONSECA S, CHICO JM, SOLANO R (2009). The jasmonate pathway: the ligand, the receptor and the core signalling module. Current Opinion in Plant Biology 12(5): 539-547. (https://doi. org/10.1016/j.pbi.2009.07.013).

FRIEDLAND AE, TZUR YB, ESVELT KM, COLAIÁCOVO MP, CHURCH GM, CALARCO JA (2013). Heritable genome editing in C. elegans via a CRISPR-Cas9 system. Nature Methods 10(8): 741-743. (https://doi.org/10.1038/nmeth.2532).

FU Y, SANDER JD, REYON D, CASCIO VM, JOUNG JK (2014). Improving CRISPR-Cas nuclease specificity using truncated guide RNAs. Nature Biotechnology 32(3): 279-284. (https://doi.org/10.1038/ nbt.2808).

GAO W, LONG L, ZHU LF, XU L, GAO WH, SUN LQ, ..., ZHANG XL (2013). Proteomic and virus-induced gene silencing (VIGS) analyses reveal that gossypol, brassinosteroids, and jasmonic acid contribute to the resistance of cotton to Verticillium dahliae. Molecular \& Cellular Proteomics 12(12): 3690-3703. (https://doi.org/10.1074/ mcp.M113.031013).

GAO Q, XU WY, YAN T, FANG XD, CAO Q, ZHANG ZJ, ..., WANG XB (2019). Rescue of a plant cytorhabdovirus as versatile expression platforms for planthopper and cereal genomic studies. New Phytologist 223(4): 2120-2133. (https://doi. org/10.1111/nph.15889).

GARNEAU JE, DUPUIS MĖ, VILLION M, ROMERO DA, BARRANGOU R, BOYAVAL P, ..., MOINEAU $S$ (2010). The CRISPR/Cas bacterial immune system cleaves bacteriophage and plasmid DNA. Nature 468(7320): 67-71. (https://doi.org/10.1038/nature09523).

GASIUNAS G, BARRANGOU R, HORVATHP, SIKSNYS $V$ (2012). Cas9-crRNA ribonucleoprotein complex mediates specific DNA cleavage for adaptive immunity in bacteria. Proceedings of the National Academy of Sciences 109(39): E2579-E2586. (https://doi.org/10.1073/pnas.1208507109).

GAUDELLI NM, KOMOR AC, REES HA, PACKER MS, BADRAN AH, BRYSON DI, LIU DR (2017). Programmable base editing of $A \bullet T$ to $G \bullet C$ in genomic DNA without DNA cleavage. Nature 551(7681): 464-471. (https://doi.org/10.1038/ nature24644).

GILBERT LA, LARSON MH, MORSUT L, LIU Z, BRAR GA, TORRES SE, ..., LIM WA (2013). CRISPR-mediated modular RNA-guided regulation of transcription in eukaryotes. Cell 154(2): 442-451. (https://doi.org/10.1016/j.cell.2013.06.044).

GIL-HUMANES J, WANG Y, LIANG Z, SHAN Q, OZU- 
NA CV, SÁNCHEZ-LEÓN S, ..., VOYTAS DF (2017). High efficiency gene targeting in hexaploid wheat using DNA replicons and CRISPR/Cas9. The Plant Journal 89(6): 1251-1262. (https://doi. org/10.1111/tpj.13446).

GIMENEZ-IBANEZ S, BOTER M, ORTIGOSA A, GARCÍA-CASADO G, CHINI A, LEWSEY MG, ..., SOLANO R (2017). JAZ 2 controls stomata dynamics during bacterial invasion. New Phytologist 213(3): 1378-1392. (https://doi.org/10.1111/ nph.14354).

GOMEZ MA, LIN ZD, MOLL T, CHAUHAN RD, HAYDEN L, RENNINGER K, ..., BART RS (2019). Simultaneous CRISPR/Cas9 mediated editing of cassava elF 4E isoforms nCBP-1 and nCBP-2 reduces cassava brown streak disease symptom severity and incidence. Plant Biotechnology Journal 17(2): 421-434. (https://doi.org/10.1111/pbi.12987).

GOMEZ MA, LIN ZD, MOLL T, LUEBBERT C, CHAUHAN RD, VIJAYARAGHAVAN A, ..., STASKAWICZ B (2017). Simultaneous CRISPR/Cas9-mediated editing of cassava elF4E isoforms nCBP-1 and nCBP-2 confers elevated resistance to cassava brown streak disease. BioRxiv, 209874. (https:// doi.org/10.1101/209874).

GOSAVI G, YAN F, REN B, KUANG Y, YAN D, ZHOU X, ZHOU H (2020). Applications of CRISPR technology in studying plant-pathogen interactions: overview and perspective. Phytopathology Research 2(1): 1-9. (https://doi.org/10.1186/s42483-02000060-z).

HAMADA H, LINGHU Q, NAGIRA Y, MIKI R, TAOKA N, IMAI R (2017). An in planta biolistic method for stable wheat transformation. Scientific reports 7(1): 1-8. (https://doi.org/10.1038/ s41598-017-11936-0).

HARPER G, OSUJI JO, HESLOP-HARRISON JS, HULL $R$ (1999). Integration of banana streak badnavirus into the Musa genome: molecular and cytogenetic evidence. Virology 255: 207-213.

HEITMAN J, HOWLETT BJ, CROUS PW, STUKENBROCK EH, JAMES TY, GOW NA (2017). The fungal kingdom. John Wiley \& Sons.

HEYER WD, EHMSEN KT, LIU J (2010). Regulation of homologous recombination in eukaryotes. Annual Review of Genetics 44: 113-139. (https://doi. org/10.1146/annurev-genet-051710-150955).

HIROYUKI S, SUSUMU K (1981). New restriction endonucleases from Flavobacterium okeanokoites
(Fokl) and Micrococcus luteus (Mlul). Gene 16(1-3): 73-78. (https://doi.org/10.1016/03781119(81)90062-7).

HORVATH P, BARRANGOU R (2010). CRISPR/Cas, the immune system of bacteria and archaea. Science 327(5962): 167-170. (10.1126/science.1179555).

HU Y, ZHANG J, JIA H, SOSSO D, LI T, FROMMER WB, ..., JONES JB (2014). Lateral organ boundaries 1 is a disease susceptibility gene for citrus bacterial canker disease. Proceedings of the $\mathrm{Na}$ tional Academy of Sciences 111(4): E521-E529. (https://doi.org/10.1073/pnas.1313271111).

HUANG TK, PUCHTA H (2019). CRISPR/Cas-mediated gene targeting in plants: finally, a turn for the better for homologous recombination. Plant Cell Reports 38(4): 443-453. (https://doi. org/10.1007/s00299-019-02379-0).

ISHINO $Y$, SHINAGAWA H, MAKINO K, AMEMURA M, NAKATA A (1987). Nucleotide sequence of the iap gene, responsible for alkaline phosphatase isozyme conversion in Escherichia coli, and identification of the gene product. Journal of Bacteriology 169(12): 5429-5433. (10.1128/ jb.169.12.5429-5433.1987).

JANSEN R, EMBDEN JDV, GAASTRA W, SCHOULS LM (2002). Identification of genes that are associated with DNA repeats in prokaryotes. Molecular Microbiology 43(6): 1565-1575. (https://doi. org/10.1046/j.1365-2958.2002.02839.x).

JI X, ZHANG H, ZHANG Y, WANG Y, GAO C (2015). Establishing a CRISPR-Cas-like immune system conferring DNA virus resistance in plants. $\mathrm{Na}$ ture Plants 1(10):1-4. (https://doi.org/10.1038/ nplants.2015.144).

JI X, SI X, ZHANG Y, ZHANG H, ZHANG F, GAO C (2018). Conferring DNA virus resistance with high specificity in plants using virus-inducible genome-editing system. Genome Biology 19(1): 1-7. (https://doi.org/10.1186/s13059-018-1580-4).

JIA H, ZHANG Y, ORBOVIĆ V, XU J, WHITE FF, JONES JB, WANG N (2017). Genome editing of the disease susceptibility gene CS LOB 1 in citrus confers resistance to citrus canker. Plant Biotechnology Journal 15(7):817-23. (https://doi.org/10.1111/ pbi.12677).

JIANG F, DOUDNA JA (2017). CRISPR-Cas9 Structures and Mechanisms. Annual Review of Biophysics 46: 505-529. (https://doi.org/10.1146/ 
annurev-biophys-062215-010822).

JIANG F, ZHOU K, MA L, GRESSEL S, DOUDNA JA (2015). A Cas9-guide RNA complex preorganized for target DNA recognition. Science 348 (5242): 1477-1481. (10.1126/science. aab1452).

JIANG N, ZHANG C, LIU JY, GUO ZH, ZHANG ZY, HAN CG, WANG Y (2019). Development of Beet necrotic yellow vein vírus based vectors for multiple gene expression and guide RNA delivery in plant genome editing. Plant Biotechnology Journal 17(7): 1302-1315. (https://doi.org/10.1111/ pbi.13055).

JINEK M, CHYLINSKI K, FONFARA I, HAUER $M$, DOUDNA JA, CHARPENTIER E (2012). A programmable dual-RNA-guided DNA endonuclease in adaptive bacterial immunity. Science 337(6096): 816-821. (10.1126/science.1225829). JUNQUEIRA C, NUNES PR, ROBERTO GM, ANNICHINI MSB (2016). CRISPR toolbox: a versatilidade da técnica. In: Pereira TC. Introdução à técnica de CRISPR. Ribeirão Preto. Sociedade Brasileira de Genética. pp. 51-69.

KAMPMANN M (2018). CRISPRi and CRISPRa screens in mammalian cells for precision biology and medicine. ACS Chemical Biology 13(2): 406-416. (https://doi.org/10.1021/acschembio.7b00657).

KANG J (2016). Application of CRISPR/Cas9-mediated genome editing for studying soybean resistance to soybean cyst nematode. Doctoral dissertation, University of Missouri--Columbia.

KANG JG, PARK JS, KO JH, KIM YS (2019). Regulation of gene expression by altered promoter methylation using a CRISPR/Cas9-mediated epigenetic editing system. Scientific Reports 9(1): 1-12. (https://doi.org/10.1038/s41598-019-48130-3).

KATIC I, GROBHANS H (2013). Targeted heritable mutation and gene conversion by Cas9-CRISPR in Caenorhabditis elegans. Genetics 195(3): 1173-1176. (https://doi.org/10.1534/genetics.113.155754).

KIM YA, MOON H, PARK CJ (2019). CRISPR/Cas9-targeted mutagenesis of Os8N3 in rice to confer resistance to Xanthomonas oryzae pv. oryzae. Rice 12(1): 1-13. (https://doi.org/10.1186/s12284019-0325-7).

KLEINSTIVER BP, PREW MS, TSAI SQ, TOPKAR VV, NGUYEN NT, ZHENG Z, ..., ARYEE MJ (2015). Engineered CRISPR-Cas9 nucleases with altered
PAM specificities. Nature 523(7561): 481-485. (https://doi.org/10.1038/nature14592).

KOMOR AC, KIM YB, PACKER MS, ZURIS JA, LIU DR (2016). Programmable editing of a target base in genomic DNA without double-stranded DNA cleavage. Nature 533(7603): 420-424. (https:// doi.org/10.1038/nature17946).

KUSCU C, ARSLAN S, SINGH R, THORPE J, ADLI M (2014). Genome-wide analysis reveals characteristics of off-target sites bound by the Cas 9 endonuclease. Nature Biotechnology 32(7): 677-683. (https://doi.org/10.1038/nbt.2916).

LI JF, NORVILLE JE, AACH J, MCCORMACK M, ZHANG D, BUSH J, ..., SHEEN J (2013). Multiplex and homologous recombination-mediated genome editing in Arabidopsis and Nicotiana benthamiana using guide RNA and Cas9. Nature Biotechnology 31(8): 688-691. (https://doi. org/10.1038/nbt.2654).

LI J, SUN Y, DU J, ZHAO Y, XIA L (2017). Generation of targeted point mutations in rice by a modified CRISPR/Cas9 system. Molecular Plant 10(3): 526-529. (https://doi.org/10.1016/j. molp.2016.12.001).

LIEBER MR (2010). The mechanism of double-strand DNA break repair by the nonhomologous DNA endjoining pathway. Annual Review of Biochemistry 79: 181-211. (https://doi.org/10.1146/annurev.biochem.052308.093131).

LIN Y, CRADICK TJ, BROWN MT, DESHMUKH H, RANJAN P, SARODE N, ... BAO G (2014). CRIS$\mathrm{PR} /$ Cas9 systems have off-target activity with insertions or deletions between target DNA and guide RNA sequences. Nucleic Acids Research 42(11): 7473-7485. (https://doi.org/10.1093/ nar/gku402).

LINO CA, HARPER JC, CARNEY JP, TIMLIN JA (2018). Delivering CRISPR: a review of the challenges and approaches. Drug Delivery 25(1): 12341257. (https://doi.org/10.1080/10717544.2018.1 474964).

LIU D, CHEN X, LIU J, YE J, GUO Z (2012). The rice ERF transcription factor OsERF922 negatively regulates resistance to Magnaporthe oryzae and salt tolerance. Journal of Experimental Botany 63(10): 3899-3911. (https://doi.org/10.1093/ jxb/ers079).

LIU H, SOYARS CL, LI J, FEI Q, HE G, PETERSON BA, ..., WANG $X$ (2018). CRISPR/Cas9 mediated re- 
sistance to cauliflower mosaic virus. Plant Direct 2(3): e00047. (https://doi.org/10.1002/pld3.47).

LIU L, LI X, WANG J, WANG M, CHEN P, YIN M, ..., WANG Y (2017). Two distant catalytic sites are responsible for $\mathrm{C2}$ c2 RNase activities. Cell 168(1-2): 121-134. (https://doi.org/10.1016/j. cell.2016.12.031).

LIU R, LIANG L, FREED EF, GILL RT (2020). Directed Evolution of CRISPR/Cas Systems for Precise Gene Editing. Trends in Biotechnology. (https:// doi.org/10.1016/j.tibtech.2020.07.005).

LIU W, LIUJ, TRIPLETT L, LEACH JE, WANG GL (2014). Novel insights into rice innate immunity against bacterial and fungal pathogens. Annual Review of Phytopathology 52: 213-241. (https://doi. org/10.1146/annurev-phyto-102313-045926).

MA J, CHEN J, WANG M, REN Y, WANG S, LEI C, CHENG Z (2018). Disruption of OsSEC3A increases the content of salicylic acid and induces plant defense responses in rice. Journal of Experimental Botany 69(5): 1051-1064. (https://doi. org/10.1093/jxb/erx458).

MA X, ZHANG X, LIU H, LI Z (2020). Highly efficient DNA-free plant genome editing using virally delivered CRISPR-Cas9. Nature Plants 6(7): 773-779. (https://doi.org/10.1038/s41477-020-0704-5).

MAEDER ML, LINDER SJ, CASCIO VM, FU Y, HO QH, JOUNG JK (2013). CRISPR RNA-guided activation of endogenous human genes. Nature Methods 10(10): 977-979. (https://doi.org/10.1038/ nmeth.2598).

MAHAS A, AMAN R, MAHFOUZ M (2019). CRISPR-Cas13d mediates robust RNA virus interference in plants. Genome biology 20(1): 1-16. (https://doi.org/10.1186/s13059-019-1881-2).

MAKAROVA KS, WOLF YI, IRANZO J, SHMAKOV SA, ALKHNBASHI OS, BROUNS SJ, ..., MOINEAU $S$ (2020). Evolutionary classification of CRISPRCas systems: a burst of class 2 and derived variants. Nature Reviews Microbiology 1-17. (https:// doi.org/10.1038/s41579-019-0299-x).

MAKHOTENKO AV, KHROMOV AV, SNIGIR EA, MAKAROVA SS, MAKAROV VV, SUPRUNOVA TP, ... , TALIANSKY ME (2019). Functional analysis of coilin in virus resistance and stress tolerance of potato Solanum tuberosum using CRISPR-Cas9 editing. In Doklady Biochemistry and Biophysics 484(1): 88-91. (https://doi.org/10.1134/ S1607672919010241).
MALNOY M, VIOLA R, JUNG MH, KOO OJ, KIM S, KIM JS, ..., NAGAMANGALA KANCHISWAMY C (2016). DNA-free genetically edited grapevine and apple protoplast using CRISPR/Cas9 ribonucleoproteins. Frontiers in Plant Science 7: 1904. (https://doi.org/10.3389/fpls.2016.01904).

MAO Z, BOZZELLA M, SELUANOV A, GORBUNOVA V (2008). Comparison of nonhomologous end joining and homologous recombination in human cells. DNA Repair 7(10): 1765-1771. (https://doi. org/10.1016/j.dnarep.2008.06.018).

MARRAFFINI LA (2015). CRISPR-Cas immunity in prokaryotes. Nature 526(7571): 55-61. (https:// doi.org/10.1038/nature15386).

MARZEC M, BRĄSZEWSKA-ZALEWSKA A, HENSEL $G$ (2020). Prime editing: a new way for genome editing. Trends in Cell Biology, 30(4): 257-259. (https://doi.org/10.1016/j.tcb.2020.01.004).

MATIĆ S, GILARDI G, GULLINO ML, GARIBALDI A (2019). Emergence of leaf spot disease on leafy vegetable and ornamental crops caused by Paramyrothecium and Albifimbria species. Phytopathology 109(6): 1053-1061. (https://doi. org/10.1094/PHYTO-10-18-0396-R).

MEHTA D, STÜRCHLER A, ANJANAPPA RB, ZAIDI SSEA, HIRSCH-HOFFMANN $M$, GRUISSEM W, VANDERSCHUREN H (2019). Linking CRISPR-Cas9 interference in cassava to the evolution of editing-resistant geminiviruses. Genome Biology 20(1): 80. (https://doi.org/10.1186/s13059019-1678-3).

MENG X, HU X, LIU Q, SONG X, GAO C, LI J, WANG $K$ (2018). Robust genome editing of CRISPR-Cas9 at NAG PAMs in rice. Science China Life Sciences 61(1): 122-125. (https://doi.org/10.1007/ s11427-017-9247-9).

MOJICA FJ, DÍEZ VILLASEÑOR C, SORIA E, JUEZ G (2000). Biological significance of a family of regularly spaced repeats in the genomes of Archaea, Bacteria and mitochondria. Molecular Microbiology 36(1): 244-246.

MOJICA FJ, GARCÍA-MARTÍNEZ J, SORIA E (2005). Intervening sequences of regularly spaced prokaryotic repeats derive from foreign genetic elements. Journal of Molecular Evolution 60(2): 174-182. (https://doi.org/10.1007/s00239-0040046-3).

MOLINARI H, VIEIRA L, SILVA N, PRADO G, LOPES FILHO JH (2020). Tecnologia CRISPR na edição 
genômica de plantas: biotecnologia aplicada à agricultura. Embrapa Agroenergia-Livro científico (ALICE).

MUÑOZ IV, SARROCCO S, MALFATTI L, BARONCE-

LLI R, VANNACCI G (2019). CRISPR-Cas for fungal genome editing: a new tool for the management of plant diseases. Frontiers in Plant Science 10: 135. (https://doi.org/10.3389/fpls.2019.00135). NAKASHITA $H$, YASUDA $M$, NITTA T, ASAMI T, FUJIOKA S, ARAI Y, ..., YOSHIDA S (2003). Brassinosteroid functions in a broad range of disease resistance in tobacco and rice. The Plant Journal 33(5): 887-898. (https://doi.org/10.1046/j.1365313X.2003.01675.x).

NEKRASOV $V$, STASKAWICZ B, WEIGEL D, JONES JD, KAMOUN S (2013). Targeted mutagenesis in the model plant Nicotiana benthamiana using Cas9 RNA-guided endonuclease. Nature Biotechnology 31(8): 691. (https://doi.org/10.1038/ nbt.2655).

NEKRASOV V, WANG C, WIN J, LANZ C, WEIGEL D, KAMOUN S (2017). Rapid generation of a transgene-free powdery mildew resistant tomato by genome deletion. Scientific Reports 7(1): 1-6. (https://doi.org/10.1038/s41598-017-00578-x).

NISHIMASU H, SHI X, ISHIGURO S, GAO L, HIRANO S, OKAZAKI S, ..., OURA S (2018). Engineered CRISPR-Cas9 nuclease with expanded targeting space. Science 361(6408): 1259-1262. (10.1126/ science.aas9129).

NISHIZAWA YOKOI A, ENDO M, OHTSUKI N, SAIKA $\mathrm{H}$, TOKI S (2015). Precision genome editing in plants via gene targeting and piggyBac-mediated marker excision. The Plant Journal 81(1): 160168. (https://doi.org/10.1111/tpj.12693).

OBSIL T, GHIRLANDO R, KLEIN DC, GANGULY $S$, DYDA F (2001). Crystal structure of the 14-3-3द: serotonin $\mathrm{N}$-acetyltransferase complex: a role for scaffolding in enzyme regulation. Cell 105(2): 257-267. (https://doi.org/10.1016/S00928674(01)00316-6).

OLIVA R, JI C, ATIENZA-GRANDE G, HUGUET-TAPIA JC, PEREZ-QUINTERO A, LI T, ... AUGUY $F$ (2019). Broad-spectrum resistance to bacterial blight in rice using genome editing. Nature Biotechnology 37(11): 1344-1350. (https://doi. org/10.1038/s41587-019-0267-z).

ORTIGOSA A, GIMENEZ IBANEZ S, LEONHARDT $N$, SOLANO R (2019). Design of a bacterial speck resistant tomato by CRISPR/Cas9 mediated editing of SI JAZ 2. Plant Biotechnology Journal 17(3): 665-673. (https://doi.org/10.1111/pbi.13006).

ÖZCAN A, PAUSCH P, LINDEN A, WULF A, SCHÜHLE K, HEIDER J, ..., RANDAU L (2019). Type IV CRISPR RNA processing and effector complex formation in Aromatoleum aromaticum. Nature Microbiology 4(1): 89-96.DOI https://doi.org/10.1038/ s41564-018-0274-8.

PAIX A, FOLKMANN A, SEYDOUX G (2017). Precision genome editing using CRISPR-Cas9 and linear repair templates in C. elegans. Methods 121: 86-93.

PAWELCZAK KS, GAVANDE NS, VANDERVERE-CAROZZA PS, TURCHI JJ (2018). Modulating DNA repair pathways to improve precision genome engineering. ACS Chemical Biology 13(2): 389-396.

POURCEL C, SALVIGNOL G, VERGNAUD G (2005). CRISPR elements in Yersinia pestis acquire new repeats by preferential uptake of bacteriophage DNA, and provide additional tools for evolutionary studies. Microbiology 151(3): 653-663. (https://doi.org/10.1099/mic.0.27437-0).

PUCHTA H (2005). The repair of double-strand breaks in plants: mechanisms and consequences for genome evolution. Journal of Experimental Botany 56(409): 1-14. (https://doi.org/10.1093/ jxb/eri025).

PYOTT DE, SHEEHAN E, MOLNAR A (2016). Engineering of CRISPR/Cas9 mediated potyvirus resistance in transgene free Arabidopsis plants. Molecular Plant Pathology 17(8):1276-88. (https:// doi.org/10.1111/mpp.12417).

RAN FA, HSU PD, WRIGHT J, AGARWALA V, SCOTT DA, ZHANG F (2013). Genome engineering using the CRISPR-Cas9 system. Nature Protocols 8(11): 2281-2308. (https://doi.org/10.1038/ nprot.2013.143).

RAN Y, LIANG Z, GAO C (2017). Current and future editing reagent delivery systems for plant genome editing. Science China Life Sciences 60(5): 490-505. (https://doi.org/10.1007/s11427-0179022-1).

SALSMAN J, DELLAIRE G (2017). Precision genome editing in the CRISPR era. Biochemistry and Cell Biology 95(2): 187-201. (https://doi.org/10.1139/ bcb-2016-0137).

SANFAÇON H (2015). Plant translation factors and 
virus resistance. Viruses 7(7):3392-419. (https:// doi.org/10.3390/v7072778).

SATHEESH V, ZHANG H, WANG X, LEI M (2019). Precise editing of plant genomes - prospects and challenges. Seminars in Cell \& Developmental Biology 96: 115-123. (https://doi.org/10.1016/j. semcdb.2019.04.010).

SCHEBEN A, WOLTER F, BATLEY J, PUCHTA H, EDWARDS D (2017). Towards CRISPR/Cas cropsbringing together genomics and genome editing. New Phytologist 216(3): 682-698. (https://doi. org/10.1111/nph.14702).

SHAN Q, WANG Y, LI J, ZHANG Y, CHEN K, LIANG Z, ..., GAO C (2013). Targeted genome modification of crop plants using a CRISPR-Cas system. Nature Biotechnology 31(8): 686-688. (https://doi. org/10.1038/nbt.2650).

SHU QY, FORSTER BP, NAKAGAWA H, NAKAGAWA $\mathrm{H}$ (Eds.) (2012). Plant mutation breeding and biotechnology. Cabi.

SINKUNAS T, GASIUNAS G, FREMAUX C, BARRANGOU R, HORVATH P, SIKSNYS V (2011). Cas3 is a single stranded DNA nuclease and ATP dependent helicase in the CRISPR/Cas immune system. The EMBO Journal 30(7): 1335-1342. (https:// doi.org/10.1038/emboj.2011.41).

SWARTS DC, JINEK M (2018). Cas9 versus Cas12a/ Cpf1: Structure-function comparisons and implications for genome editing. Wiley Interdisciplinary Reviews: RNA 9(5): 1-19. (https://doi. org/10.1002/wrna.1481).

SWARTS DC, VAN DER OOST J, JINEK M (2017). Structural basis for guide RNA processing and seed dependent DNA targeting by CRISPR Cas12a. Molecular Cell 66: 221-233. (https://doi. org/10.1016/j.molcel.2017.03.016).

TAMURA K, ADACHI Y, CHIBA K, OGUCHI K, TAKAHASHI H (2002). Identification of Ku70 and Ku80 homologues in Arabidopsis thaliana: evidence for a role in the repair of DNA double strand breaks. The Plant Journal 29(6): 771-781. (https://doi. org/10.1046/j.1365-313X.2002.01258.x).

TANENBAUM ME, GILBERT LA, QI LS, WEISSMAN JS, VALE RD (2014). A protein-tagging system for signal amplification in gene expression and fluorescence imaging. Cell 159(3): 635-646. (https:// doi.org/10.1016/j.cell.2014.09.039).

TASHKANDI M, ALI Z, ALJEDAANI F, SHAMI A, MAHFOUZ MM (2018). Engineering resistance against Tomato yellow leaf curl virus via the CRISPR/Cas9 system in tomato. Plant Signaling \& Behavior 13(10): e1525996. (https://doi.org/10.108 0/15592324.2018.1525996).

TRIPATHI JN, NTUI VO, RON M, MUIRURI SK, BRITT A, TRIPATHI L (2019). CRISPR/Cas9 editing of endogenous banana streak virus in the $B$ genome of Musa spp. overcomes a major challenge in banana breeding. Communications Biology 2(1): 1-11. (https://doi.org/10.1038/s42003-019-0288-7).

TSAI SQ, WYVEKENS N, KHAYTER C, FODEN JA, THAPAR V, REYON D, ..., JOUNG JK (2014). Dimeric CRISPR RNA-guided Fokl nucleases for highly specific genome editing. Nature Biotechnology 32(6): 569-576. (https://doi.org/10.1038/ nbt.2908).

TSANKOV AM, GU H, AKOPIAN V, ZILLER MJ, DONAGHEY J, AMIT I, ..., MEISSNER A (2015). Transcription factor binding dynamics during human ES cell differentiation. Nature 518(7539): 344349. (https://doi.org/10.1038/nature14233).

TZUR YB, FRIEDLAND AE, NADARAJAN S, CHURCH GM, CALARCO JA, COLAIÁCOVO MP (2013). Heritable custom genomic modifications in Caenorhabditis elegans via a CRISPR-Cas9 system. Genetics 195(3): 1181-1185. (https://doi. org/10.1534/genetics.113.156075).

VIEIRA LR, FREITAS NC, JUSTEN F, MIRANDA VDJ, GARCIA BDO, NEPOMUCENO A, ..., PINTO EDC (2020). Regulamentação da edição genômica em plantas no Brasil e no mundo. Embrapa Agroenergia-Capítulo em livro científico (ALICE).

VIEIRA GV, CECÍLIO NT, ARRUDA LM, SALES KU (2016). Visão geral do mecanismo básico de ação. Introdução à técnica de CRISPR. 1a edição. Ribeirão Preto, Sociedade Brasileira de Genética, 39-50.

VIEIRA LR, FREITAS NC, JUSTEN F, MIRANDA VJ, ..., KOBAYASHI AK (2020). Regulamentação da edição genômica em plantas no Brasil e no mundo. In: Molinari HBC, ... (Eds.) Tecnologia CRISPR na edição genômica de plantas: biotecnologia aplicada à agricultura. Brasília: Embrapa. pp. 179-207.

VRIET C, RUSSINOVA E, REUZEAU C (2012). Boosting crop yields with plant steroids. The Plant Cell 24(3): 842-857. (https://doi.org/10.1105/ tpc.111.094912).

VU TV, SUNG YW, KIM J, DOAN DTH, TRAN MT, KIM JY (2019). Challenges and Perspectives in 
Homology-Directed Gene Targeting in Monocot Plants. Rice 12(1): 1-29. (https://doi.org/10.1186/ s12284-019-0355-1).

WAAIJERS S, PORTEGIJS V, KERVER J, LEMMENS

BB, TIJSTERMAN M, VAN DEN HEUVEL S, BOXEM M (2013). CRISPR/Cas9-targeted mutagenesis in Caenorhabditis elegans. Genetics 195(3): 1187-1191. (https://doi.org/10.1534/genetics.113.156299).

WANG F, WANG C, LIU P, LEI C, HAO W, GAO Y, ..., ZHAO K (2016). Enhanced rice blast resistance by CRISPR/Cas9-targeted mutagenesis of the ERF transcription factor gene OsERF922. PloS One 11(4). (https://doi.org/10.1371/journal. pone.0154027).

WANG K, WANG Z, LI F, YE W, WANG J, SONG G, ..., ZOU C (2012). The draft genome of a diploid cotton Gossypium raimondii. Nature genetics 44(10): 1098-1103. (https://doi.org/10.1038/ng.2371).

WANG Y, CHENG $X$, SHAN Q, ZHANG Y, LIU J, GAO C, QIU JL (2014). Simultaneous editing of three homoeoalleles in hexaploid bread wheat confers heritable resistance to powdery mildew. Nature Biotechnology 32(9): 947. (https://doi. org/10.1038/nbt.2969).

XIE K, YANG Y (2013). RNA-guided genome editing in plants using a CRISPR-Cas system. Molecular Plant 6(6): 1975-1983. (https://doi.org/10.1093/ $\mathrm{mp} / \mathrm{sst119)}$.

YANG H, PATEL DJ (2019). CasX: a new and small CRISPR gene-editing protein. Cell Research 29(5): 345-346. (https://doi.org/10.1038/s41422-0190165-4).

YANG K, GUO R, XU D (2016). Non-homologous end joining: advances and frontiers. Acta Biochimica et Biophysica Sinica 48(7): 632-640. (https://doi. org/10.1093/abbs/gmw046).

YIN K, HAN T, LIU G, CHEN T, WANG Y, YU AYL, LIU $Y$ (2015). A geminivirus-based guide RNA delivery system for CRISPR/Cas9 mediated plant genome editing. Scientific Reports 5: 14926. (https://doi. org/10.1038/srep14926).

YIN K, QIU JL (2019). Genome editing for plant disease resistance: applications and perspectives. Philosophical Transactions of the Royal Society B 374(1767): 20180322. (https://doi.org/10.1098/ rstb.2018.0322).

YIN K, HAN T, XIE K, ZHAO J, SONG J, LIU Y (2019). Engineer complete resistance to Cotton Leaf Curl
Multan virus by the CRISPR/Cas9 system in $\mathrm{Ni}$ cotiana benthamiana. Phytopathology Research 1(1): 1-9. (https://doi.org/10.1186/s42483-0190017-7).

ZETSCHE B, GOOTENBERG JS, ABUDAYYEH OO, SLAYMAKER IM, MAKAROVA KS, ESSLETZBICHLER P, VOLZ SE, JOUNG J, VAN DER OOST J, REGEV A, KOONIN EV, ZHANG F (2015). Cpf1 is a single RNA-guided endonuclease of a class 2 CRISPR-Cas system. Cell 163(3): 759-771. (https://doi.org/10.1016/j.cell.2015.09.038).

ZHANG T, ZHENG Q, YI X, AN H, ZHAO Y, MA S, ZHOU G (2018). Establishing RNA virus resistance in plants by harnessing CRISPR immune system. Plant Biotechnology Journal 16(8):1415-23. (https://doi.org/10.1111/pbi.12881).

ZHANG Y, BAI Y, WU G, ZOU S, CHEN Y, GAO C, TANG D (2017). Simultaneous modification of three homoeologs of Ta EDR 1 by genome editing enhances powdery mildew resistance in wheat. The Plant Journal 91(4):714-24. (https://doi. org/10.1111/tpj.13599).

ZHANG Z, GE X, LUO X, WANG P, FAN Q, HU G, ..., WU J (2018b). Simultaneous editing of two copies of Gh14-3-3d confers enhanced transgene-clean plant defense against Verticillium dahliae in allotetraploid upland cotton. Frontiers in Plant Science 9:842. (https://doi.org/10.3389/ fpls.2018.00842).

ZHAO X, MENG Z, WANG Y, CHEN W, SUN C, CUI B, ..., LUO D (2017). Pollen magnetofection for genetic modification with magnetic nanoparticles as gene carriers. Nature Plants 3(12): 956-964. (https://doi.org/10.1038/s41477-017-0063-z).

ZHOU J, PENG Z, LONG J, SOSSO D, LIU B, EOM JS, ..., WHITE FF (2015). Gene targeting by the TAL effector PthXo2 reveals cryptic resistance gene for bacterial blight of rice. The Plant Journal 82(4): 632-643. CRISPR-Cas system. Cell 163(3): 759-771. (https://doi.org/10.1111/tpj.12838).

ZHU H, LI C, GAO C (2020). Applications of CRIS$\mathrm{PR}-\mathrm{Cas}$ in agriculture and plant biotechnology. Nature Reviews Molecular Cell Biology 21(11): 661-77. (https://doi.org/10.1038/s41580-02000288-9).

ZAIDI SS, MAHFOUZ MM, MANSOOR S (2017). CRISPR-Cpf1: a new tool for plant genome editing. Trends in Plant Science 22: 550-553. (doi: 10.1016/j.tplants.2017.05.001). 